\title{
Lenguaje y Modernismo Peruano del Siglo XVIII
}

\author{
Por Pablo Macera 'Dall'Orso
}

1. ¿Cómo hablaban o, al menos, cómo hubiesen querido hablar y escribir los peruanos cultos del siglo XVIII? A nadie ha preocupado esta pregunta ( $\mathrm{si}$ exceptuamos un opúsculo del padre Vargas Ugarte sobre la oratoria sagrada de la Colonia) ${ }^{1}$. El interés de nuestros "especialistas en las ideas del siglo XVIII" se ha dirigido hacia las expresiones políticas o pedagógicas del modernísmo peruano sin advertir que los propios textos consultados ofrecían por sí mismos, como hechos de lenguaje, una prueba de las transformaciones ideológicas que se pretendía estudiar; o que en su defecto y sin recurrir al análisis filológico, abundaban en aquellos textos declaraciones explícitas acerca de los ideales lingüísticos, parte principal de los objetivos culturales de la época. Una historia del modernismo debería comprender un estudio del modernismo al' nivébidel lenguajel mediantela laconvergencia de dos tareas distintas pero complementarias: a) un análisis filológico de los múltiples textos (científicos, filosóficos, literarios, etc...) buscando aquello que diferenciándolos de la tradición barroca atestiguase el cambio aportado por el modernismo a los estilos literarios; b) una historia de las ideas lingüísticas -bosquejada en estas páginas- o mejor dicho de las ideas, espectativas, ideales y prejuicios lingüísticos de un intelectual peruano de mediados del sigio XVIII. El objeto de ambas indagaciones constituye un sector excepcionalmente privilegiado para quien desee reconocer el desarrollo del pensamiento moderno en el Perú colonial. No sólo porque una imagen cualquiera del universo, en nuestro caso la surgida durante el siglo XVIII, supone la construcción paralela y simultánea de sus propios medios expresivos y entre ellos de su lenguaje (una inflexión particular del idioma) sino además porque en el curso de aquella construcción se definen muchas ve- 
ces con cierta anterioridad las ideas que después se manifiestan en el pensamiento teórico o en la acción política. De esa prioridad se tuvo conciencia durante el siglo XVIII, pues en la medida, por ejemplo, que un teólogo, un historiador o un científico prelendiera en España y sus colonias, reformar su disciplina, tropezaba siempre con el mismo obstáculo: el instrumento lingüístico a su alcance era inadecuado, respondía a otros principios de formación que los suyos, a una finalidad y a una visión de las cosas que el el siglo XVIII desdeñaba. Las dificultades del lenguaje, sus anacronismos e insuficiencias, aparecían, por consiguiente, en los medios intelectuales más avanzados, como una cuestión previa a resolver ${ }^{2}$.

Existe por último una circunstancia adicional en el caso de las colonias españolas de América, que al lado de las precedentes determina la razón de este estudio. Como las discusiones lingüísticas carecieron a los ojos de la Iglesia y del Estado, de mayor significación ideológica, se disfrutó al respecto de una cierta tolerancia, de una cierta clase de libertad de pensamiento. La habitual cautela en el caso de materias filosóficas o religiosas no fue necesaria en esas discusiones. Un partidario del jansenismo tenía buenas razones para temer el peligroso calificativo de hereje, un simpatizante de Montesquieu o de Mably quizás el de rebelde, pero quien prefiriese el castellano al latín o la simplicidad neoclásica en vez del cohceptismo se hallabasa salvo de casi todas las sospechas oficiales. El denqugie fue gsí un vehículo ideológico más poderoso que la abierta propaganda política ${ }^{3}$ y sin exagerar demasiado podría incluso decirse que con la liquidación de las tradiciones lingüísticas del siglo XVII empezó la liquidación de la cultura y de la sociedad españolas del virreinato.

No se ha de exagerar sinembargo la importancia social de esás inquietudes lingüísticas modernas; sirven de buen síntoma, de testimonio a veces prioritario de la introducción del pensamiento moderno en el Perú; pero no más. Pues esas inquietudes constituyeron el privilegio de un puñado de hombres, de una minoría cuyos ideales apenas si influyeron sobre los otros grupos sociales. Geográfica y sozialmente el modernismo se recluyó en unos cuantos sectores de la población urbana blanca (algunos de los europeos y criollos). Sus opiniones fueron prestadas, imitadas de Europa, trasplantadas al continente americano con el fin, no tanto o no sólo de "modernizar" de conocer y amar al país (Los Áman- 
tes del País) como también de europeízarlo *. Ese doble carácter imitativo y minoritario, fue una de las causas de su fracaso o si se prefiere de algunas de sus más graves limitaciones ${ }^{5}$.

2. Las ideas lingüísticas modernas no aparecieron en el $\mathrm{Pe}$ rú de la noche a la mañana, maduras y hechas, todas ellas en un solo momento. Es arriesgado establecer una cronología, pero los texlos sugieren que hasta muy avanzado el siglo XVIII los intelectuales percibieron el lenguaje como un hecho artístico, en vinculación con ciertas cuestiones de orden estético o religioso. Sus principales temas fueron: los defectos del barroco, los neologismos, el afrancesamiento del idioma español y la reforma de la oratoria sagrada. Mientras que a principios del siglo XIX y aunque subsistiendo las preocupaciones iniciales, predominó el interés por descubrir las ventajas del idioma español sobre el latín como instrumento de investigación y de divulgación científica. En ninguno de esos períodos hubo una verdadera inquietud por la expresión oral y cuotidiana ni por cualquier otro nivel de la lengua que no fuese el nivel minoritario y estrecho del idioma culto, del idioma literario de los escritores.

El desarrollo de las ideas lingüísticas - que de la consideración estética concluye en la científica- y su alejamiento deliberado de los problemas diarios del habla, coincidió en el Perú con las etapas del pensamiento moderno. Este pensamiento -o en general la actitud moderna ante el mundo- no llegó hasta nosotros, al principio, bajo la forma de leorías físicas o de doctrinas políticas sino como el ejemploodeleuna cnueval isensibilidad" Así, qquellos mismos que combatieron en el Perú durante el siglo XVIII a la filosofía moderna o que la ignoraron por completo, se sometieron, no obstante, a los dictados de una reciente moda extranjera $y$ arreglaron sus casas, sus vestidos o sus discursos de acuerdo a un nuevo ideal de belleza. Cuando empezaron en el Perú las polémicas doctrinales entre los conservadores y los modernistas hacía ya largo tiempo que los ideales europeos del siglo XVIII se habían introducido entre nosotros. Una historia de las artes domésticas podría demostrarlo. Los primeros mensajes del modernismo fueron el mueble, la joya, el adorno de las casas, los empastes, todas aquellas creaciones minúsculas que constituyen la circunstancia inmediata del hombre y que el erudito descuida. El cuerpo, los sentidos, la sensibilidad, estuvieron pues familiarizados con lo moderno antes que la inteligencia; la idea escrita llegó después o fue aceptada después. 
En esta perspectiva, el inteleciual criollo contó a mediados del siglo XVIII con un cuadro de referencias inmediatas al cual vincular su posición frente al lenguaje. La belleza o la fealdad del idioma precedieron como vivencias a toda consideración erudita acerca del neologismo o acerca de las ventajas científicas del idioma vulgar. La primera tarea consistió en organizar la sensibilidad y en eliminar los evidentes desacuerdos enire un lenguaje envejecido - el lenguaje barroco y conceptista- y las nuevas aspiraciones del gusto. De ahí, porque en el Perú lo moderno fue antes sentimiento que reflexión, que los primeros testimonios dęl interés crítico por el idioma se consagraran a examinar la deccxdencia estética del castellano. La decadencia estética, sinembargo, implicó el plánteamiento de cuestiones que excedieron su propio dominio. En parte porque el siglo XVIII no dudó de la unidad ín-. tima de ciertos valores (Bien, Belleza, Verdad) y también porque en España la desfiguración del idioma aparecía como uno de los resultados, como un aspecto parcial y sintomático de una crisis mayor que comprendiendo a lás Artes aquejaba en última instancia a todas las estructuras sociales del Imperio español.

\section{Ruiz Cano y los Júbilos de Lima}

3. El precursor de estas inquietudes estéticas fue enire nosotros Francisco Ruiz Cano, aristócraiá criollo a quien Raúl Porras adjudica el cáustico Drama delos Palanganas, escrito contra el Virrey Amat ${ }^{6}$. Ruiz Cano perteneció a las primeras generaciones modernistas peruanas y junto con Bravo de Lagunas y el panameño Gorrichategui divulgó medio siglo antes que los Amantes del País el programa ideológico del modernismo europeo. En 1755, muy joven aún, Ruiz Cano publicó unos Júbiios de Lima que por el título y por el asunto (celebrar la restauración de la Catedral destruída en 1746; celebrar los méritos del Virrey Superunda) poco o nada tendría que ver con nuestro estudio; pero bajo esas apariencias de lisonja los Júbilos de Lima constituyen el testimonio temprano, quizás vacilante, de la nueva sensibilidad del siglo XVIII. Ruiz Cano no quiso escribir un panegírico sino confrontar pacientemente la arquilectura moderna y la arquitectura barroca y a través de este examen, sin olvidar una original defensa de la arquitectura criolla, decir cuáles eran las aspiraciones estéticas de su época. Y aunque no se interesó particularmente por los proble- 
mas estéticos del lenguaje, sus planteamientos suponen aquellos problemas y aluden explícilamente a ellos ciertas veces. Lo que él dijo acerca de la correspondencia entre los estilos literarios y arquitectónicos y acerca de la racionalidad, jusia proporción y sencillez del idioma, aunque breve y hasla confuso, anunciaba las posteriores críticas contra el lenguaje barroco, proporcionando a esas críticas no sólo un antecedente (lo cual carecería hasta cierto punto de importancia) sinó también una fundaməntación teórica general.

El libro de Ruiz Cano comenzaba por una disertación sobre las relaciones entre la Belleza y la Verdad. El fundamento estético de la arquitectura -y por extensión del lenguaje- implicaba un planteamiento gnoseológico previo. Desde este punto de vista, la Belleza, según Ruiz Cano, venía a ser auxiliar del conocimiento. "Nada pudiera ser en mayor perjuicio de la verdad que el espíritu de aquella máxima que manda pintarla desnuda. Nunca quedará más oculia que cuando de este modo se presumiese hacerla más patente. El empeño de disfrazarla no podría lograr sus fines con más felicialad que este cuidado de hacerla manifiesta". El buen o mal gusto de una obra cualquiera, su fealdad - su belleza comprometía la yerdad intrínseca que se buscaba manifestar a través de ellas. A semejanza, lejana, es cierto, y casual, con Diderot, quien había más tarde de identificar Bien y Belleza, Etica y Estética, Ruiz Cano supuso que el Universo constituía un Joaje únicocien lel Cquevnôsera posible separar al ser de sus apariencias o manifestaciones. Si el cristianismo ilustrado o moderno (no discutiremos por ahora la conveniencia de estos calificativos) acordaba al culto exterior un primer rango en la vida religiosa, era por una razón semejante. En uno y en otro caso, se tratase de la Feligión o de la Arquitectura y Lenguaje, la expresión constituía un elemento esencial. El culto religioso, el idioma y la pintura venían a ser realidades semánticas, símbolos o comunicaciones y lo que en este orden se denominaba "forma" no podía razonablemente ser opues!o o inferior a los "contenidos". Entre ambos existía, por otra parte, una identificación de hecho al manifestarse conjuntamente gracias al acto creador que las reunía; identificación de hecho que asimismo se reproducía en el acto del conocimiento y que, como Ruiz Cano había de decir páginas después, correspondía a la constitución propia del ser humano. 
4. En la base de estas afirmaciones que describían al mundo como una totalidad de funciones y de dependencias mutuas (muy de acuerdo con la imagen que de la sociedad tenían los intelectuales criollos del siglo XVIII) se hallaban nociones muY precisas acerca de lo que fuera el hombre; nociones precisas pero no siempre coherentes; una antropología y una metafísica, si el primero de esos nombres cabe, al mismo tiempo moderna y cristiana. El hombre que para Ruiz Cano no podía vivir ni conocer Verdades Desnudas -que en definitiva eran Verdades Ocultas- se definía por su complejidad, por la coexistencia y el equilibrio de fuerzas opuestas, sin que pudiéramos legítimamente reducirlo a una sola de ellas. El hombre no era un ser de razón, ni un ser de sentidos, ni un ser de imaginaciones, sino todo ello a la vez y algo más. Y de lo que fuera este hombre dependía el puesto que en su mundo desempeñaban la Belleza y la Verdad. En otras palabras y por remisiones sucesivas, lo que debió ser una comparación banal entre dos estilos arquitectónicos se convirtió en una visión global que de una primera aproximación sobre los valores y el conocimiento concluía en el análisis concreto aunque sumario de las facultades humanas.

Ruiz Cano se limitó por desgracia a comprobaciones que hoy pasan por lugares comunes. Sin embargo, cuando las escribió en Lima, gozaron de una cierta novedad. Si la Verdad requería de la belleza era en definitiva porque el hombre no conocía exclusivamente a través delciaciocinioni pioroun acto del espíritu. En él hallábamos el cuerpo, los sueños, el instinto; antes de razonar, deseaba o sentía y sólo mediante un esfuerzo purgativo y armonizador accedía a la inteligencia de las cosas. "Lo racional está muy a espaldas de lo sensible. Su espíritu (el del hombre) no es dueño: es prisionero de la imaginación. Esta si no la mejor es la más poderosa de las potencias" ${ }^{\prime 7}$. El conocimiento requería pues del permiso o de la intervención de todas esas facultades extraracionales. La razón yacía en el hombre como una prisionera; no se hallaba en contacto directo con las cosas sino que todas las noticias exteriores le venían a través de lo que Ruiz Cano llamaba "las cinco puertas de la razón, cuya entrada defienden muy a satisfacción de su dueño los sentidos" 8 .

Esta concepción dinámica y eventualmente conflictiva del hombre (La Razón prisionera y la Imaginación la más poderosa pero no la mejor de nuestra facultades) escondía. una convicción 
racionalista que Ruiz Cano pudo recoger de los autores europeos del siglo XVIII. Por racionalismo no se entendía entonces, ni aquí, la opinión gratuita y superficial que consiste en decir que el hombre es por naturaleza y definitivamente un ser exclusivamente racional. Todo lo contrario: para Ruiz Cano como para los racionalistas europeos del XVIII un hombre y un mundo racionales constituía una aspiración límite y no un hecho adquirido. La razón era la primera de las potencias humanas en derecho pero no de hecho. En el dominio psicológico, los racionalistas no ignoraban la importancia efectiva de las pasiones, del instinto y de las fuerzas que escapaban al control de la inteligencia consciente y que usurpaban el puesto de la razón. Denunciaban al contrario la existencia de esas fuerzas como un peligro constante en la medida que rompiendo el equilibrio original del hombre (equilibrio divino o natural, según los casos y autores) tiranizaban al espíritu. En este sentido la versión de la naturaleza humana que propuso el racionalismo del siglo XVIII no pasó de ser una laicalización de la imagen ascétíca del cristiano. El hombre (el cristiano) se encontraba en una tensión perpetua -era un ser de fronteras según desde un punto de vista diferente había dicho Pascal en el siglo XVII- luchando consigo mismo para vencer las tendencias negativas de su naturaleza y acceder penosamente al nivel superior del entendimiento (o de la salvación).

La Belleza surgida, en parte al menos, de los sentidos y de la imaginación, la Bêlleza quecnónerai fazón pura y en contacto estrecho con las cosas constituía la mediación entre la Razón y las cosas. El oficio de las artes no era por tanto ajeno al del pensamiento. A las artes que manifestaban la belleza, correspondía franquear los obstáculos sensoriales e imaginativos y conducir el mensaje de la Verdad, abrir un camino a la Verdad. En el esquema de Ruiz Cano, esquema de un pensamiento y no más, esa definición instrumental y racionalista de la belleza suplantó muchas veces a la belleza misma. En lugar de una identificación entre el conocimiento racional y la intuición estética 0 entre los diversos valores $\circ$ de conceder una autonomía y un carácter propio a lo bello, Ruiz Cano, contradiciendo alguna premisa suya, prefirió por momentos establecer implícitamente una jerarquía de las actividades del espíritu, según la cual todas ellas se encontraban supeditadas al entendimiento racional. La fealdad del gótico, por ejemplo, fue denunciada en los Júbilos de Lima en tanto que vehículo 
del error y de la mentira, como negación de la verdad y no sólo porque en sí misma fuera una negación de la bəlleza ${ }^{9}$. El pensamiento de Ruiz Cano no ha sido al respecto muy claro. No hay que olvidar que por entonces el modernismo en el Perú era apenas una novedad o una promesa, como lo revelaba el prop:o estilo de Ruiz Cano, tan cerca en algunas de sus páginas de los antiguos modelos oratorios; y que en un período de transición culiural como el de entonces, la confusión y la oscuridad constituyen frecuentemente una regla.

5. Después de esta reflexión preliminar sobre la condición humana y el valor cognoscitivo de la Belleza, Ruiz Cano consideró en los Júbilos de Lima los problemas estélicos particulares que concernían a la arquitectura y por exiensión más o menos explícita al lenguaje, a la música y a la pintura. La sobriedad, el acuerdo entre las partes, la sencillez, se presentaban en el universo para Ruiz Cano como una regla estética casi divina. La imitación fiel de la Naturaleza y de los altos ejemplos del clasicismo resumían en pocas palabras las normas indispensables para obtener la belleza. "Lo verdadero... no se halla sino en la naluraleza o es la Naturaleza misma según lo pensaba un bello espíritu de la Francia". Lo verdadero es decir lo bello; pues la arcuitectura aquí preferencialmente considerada no constituía un ejercicio de la fantasía, de la innovación extravaganie sino una ciencia rigurosa cuyo principal objetivo era la solidezly permanencia de las fábricas. De ahí que el estilo arquitectónico más censurable fuera el estilo gótico, grosero e irregular, impuesto por los "bárbaros del Norte"; de ahí también que el verdadero arquitecto, aquel que conocía los deberes y las aspiraciones de su oficio-ciencia, jamás hubiera usado las columnas espirales. En ambos casos -el gótico medie$\mathrm{val}$ y las. columnas salomónicas- se violaba la ley de la economía de los medios, de la armonía y sencillez; ley universal que Ruiz Cano encontraba no sólo en las obras de la Naturaleza inanimada sino también en el organismo humano y en el propio "cuerpo" de las sociedades. Pues si el edificio arquitectónico, fueron sus palabras tenía una especie o simulacro de vida ("del cual es alma la proporción"), las ciudades se formaban por unión de los edificios y por la agregación racional de funciones como los cuerpor materiales se constituían a partir de sus órganos.

El lenguaje se hallaba asimismo sometido a esas exigencias simples y racionales que en la arquitectura y el cuerpo o la vida 
social mantenían inalterable la regularidad del mundo. Lo dicho acerca de la arquitectura -entendida como ejemplo- valía para todas las demás artes y creaciones del espíritu. Algunas veces en forma particular y debido a una semejanza de procedimientos: así la música que Ruiz Cano definía como una arquitectura de los sonidos del mismo modo que a su vez la arquitectura era una música de las medidas ${ }^{10}$. En todo caso, Música, Lenguaje, Pintura, y al margen de esas similitudes particulares, las reglas de la belleza arquitectónica se aplicaban y trasferían en virtud de la correspondencia esencial ya aludida entre todas las actividades del espíritu. La Belleza siendo una sola, un falso lenguaje implicaba necesariamente un error una fealdad paralela, en la arquitectura - en la música. Los pueblos escribían o hablaban con el mismo estilo que empleaban en construir sus casas; y esto no constituía un fenómeno casual ni una simple coincidencia cronológica sino al contrario, la manifestación simultánea y múltiple de un solo tipo de sensibilidad ${ }^{11}$. Para convencerse de estas hipótesis, en parte tácitamente expresadas por los Júbilos de Lima, bastaba observar el desarrollo de las artes en un período determinado: "Parecía (entonces) dice Ruiz Cano que los escritores afectaban hacerse ininteligibles y sólo pretendían deslumbrar al espíritu para agrandarlo. Los arquitectos con el mismo cuydado escondían su dibuxo entre una infinidad de molduras aspirando a lisonjear con la confusión".

En pocas palabras y $\sin$ conceder mayor atençión al lenguaje, los Júbilos de Lima resumían los ideales estéticos y lingüísticos de la cultura moderna. En todos los dominios del espíritu había que reimplantar las normas primitivas de sencillez; el lenguaje racional y moderno debía de seguir el ejemplo de la arquitectura y olvidar las oscuridades y el artificio. Ruiz Cano sólo dejó entrever por desgracia cuales eran los defectos que se reprochaba al lenguaje literario del siglo XVIII, sin mencionar tampoco los medios que le servirían de reforma. Dentro de sus propósitos, por cierto, no cabía ese género de reflexiones. Su mérito consistió en haber incluído los problemas artísticos del lenguaje dentro de un contexto más amplio que comprendía a todas las manifestaciones estéticas. La decadencia del castellano no venía a ser así de la competencia exclusiva de los literatos ni una crisis accidental de segundo orden sino un hecho que debía de ser juzgado y resuelto al nivel de todo el proceso de la cultura. 


\section{La Oratoria Sagrada.}

6. Los ideales estéticos barrocos o conceptistas persistieron en el Perú hasta muy avanzado el siglo XVIII. Años antes, en 1662 El Lunarejo había definido esos ideales cuando dijo que la escritura secular, a diferencia de la sagrada, debía de ser "todo adorno de dicciones, toda pompa de palabras, todo aliño de elocuencias", añadiendo que así yacía vana, hueca y sin corazón de misterio. Las cátedras y los púlpitos coloniales obedecieron ciegamente esos consejos. Nosotros podemos imaginar los resultados leyendo las prédicas de nuestros oradores religiosos en nada mejores ni diferentes a los españoles; y recurriendo a las Artes Manuales del orador cristiano que hasta fines del siglo XVII sirvieron de guía literaria al sacerdote de las Indias. Sin pretender una caracterización exhaustiva, puede decirse que toda aquella literatura y en especial la predicación sagrada se distinguió por la abundancia de metáforas, su estilo afectado, la mezcla $\circ$ confusión de los temas profanos y sagrados, la erudición inoportuna y el abuso de citas marginales ${ }^{12}$.

La crítica de esos vicios literarios surgió en el Perú como ha de verse en los alrededores de 1750 y no fue iniciativa exclusiva de los laicos o de los eclesiásticos, ni tuvo objetivos puramente literarios. Cada una de estas afirmaciones merece una discusión particular.

En páginas anferiores quedal dichoveomo" la reforma del Lenguaje constituyó durante el siglo XVIII sólo una de las varias manifestaciones del pensamiento moderno. Los principios y las reglas adoptados en favor del Lenguaje valieron también para la Economía, el Derecho, la Arquitectura o la Política; pues en tanto que aspectos de la realidad, todos poseían una estructura idéntica: De lo inorgánico al Espíritu, de la Naturaleza al Hombre -incluyendo las obras colectivas de su cultura- el universo participaba de la racionalidad del Dios Creador. En virtud de esta racionalidad generalizada el hombre de estudio no podía ni debía ser un especialista. Conocer significaba para ese hombre descubrir y poner en evidencia lo universal en lo particular, sin permanecer ajeno a ninguna duda, pregunta o problema; de tal modo que el conocimiento científico casi se identificara con una visión filosófica que abrazara y reconstruyera la armonía de todas las cosas. Hubo así durante el siglo XVIII en el Perú como en Europa una cierta 
vocación enciclopédica, diferente al enciclopedismo acumulativo del barroco, que tácitamente autorizaba a que todo hombre medianamente culto, con ayuda de sus "luces naturales", es decir de su razón, opinase sobre cualquier cuestión por lejana que parecie. se de sus intereses más inmediatos. El médico Unanue hubo de ocuparse de geografía y de historia, el teólogo Gonzáles Laguna de la medicina y la botánica, el abogado Pinto de estadística, el Oidor Cerdán de la historia, el economista Feyjóo de patrística y comentarios bíblicos, el Obispo Martínez Compañón de arqueología, entre otras cosas; Baquíjano de política y teología morali el marqués de Valleumbroso de paleontología, lenguas modernas, física y filosofía. Los ejemplos podrían multiplićarse indefinidamente. Un tomo de El Mercurio Peruano, en cuyas páginas la última generación modernista expresó sus inquietudes, contiene en obediencia a esta curiosidad universal del hombre de letras, desde un cuadro estadístico, de muertes o de mercaderías, hasta una disertación de Rodríguez de Mendoza sobre los planes educativos o una poesía o mal verso de Pastor de Larrinaga, sin excluir descripciones geográficas, diccionarios de voces científicas, críticas a la oratoria sagrada, artículos de costumbres y monografías históricas y de ciencias naturales. Y si por la fecha de publicación -fines del siglo XVIII- y por su índole de revisia generacional, se arguyera que aquella diversidad de temas constituye un fenómeno singular muy tardía, lbastaría fecorrer las publicaciones anteriores que desde mediados de sigle XVHIlen adelante divulgaron el ideario modernista en nuestra Colonia. Los Sermones y Relaciones de Fiestas de aquellos años, forma oficial y pasajera utilizada de preferencia por los intelectuales criollos y españoles, se apartaban frecuentemente de los temas obligatorios confesados por sus propios títulos. Y lo que prometía ser un elogio al gobernante de turno, como en los Júbilos de Lima, terminaba por convertirse en una exposición sobre la arquitectura o el lenguaje. Las Aprobaciones y las Cartas al Autor que precedían a los textos, observaban iguales normas. Tras de un elogio siempre indulgente surgían en el curso de apenas dos o tres páginas todos los temas y polémicas que preocupaban a los defensores del modernismo, como si el tiempo y el espacio, las oportunidades de decir y de hacerse escuchar fueran escasas (en realidad lo eran) ${ }^{13}$.

No hubo dentro de esos intelectuales modernistas, prontos a decir su opinión sobre el universo entero, casi ninguno que no sin- 
tiera alguina vez la necesidad de pronunciarse acerca de la oratoria sagrada, explicando los defectos del barroco y las virtudes del nuevo régimen literario propuesto por la cultura moderna. Junto a los eclesiásticos (el agustino Cuervo, los jesuitas Sánchez y Rivero, Echague, el mercedario Calatayud, Bermúdez, Fray José Freyre, etc....) figuraron civiles célebres por su radical adhesión al modernismo: Baquíjano y Carrillo, Ruiz Cano, el Concle de las Torres, Sánchez Carrión, Arriz, en una enumeración ni cronológica ni exhaustiva que nos prueba que la reforma de la predicación fue entre nosotros algo más que un pleito de familia entre la gente de Iglesia. Es dificícil saber aquien correspondió la iniciativa en esas críticas, si a los laicos o a los eclesiásticos. Al menos y conIra lo que se repite es preciso insistir que estos últimos fieron tan entusiastas como los otros y que el pensamiento moderno no puede históricamente separarse de la actividad de ciertos sec!ores eclesiásticos que lucharon durante el siglo $x$ VIII por reconciliar los principios de la Fé con la Razón Y por demostrar que la sensibiaad moderna no era incompatible con el cristianismo.

Esa críica de la oratoria sagrada ejercida por la clase dirigente y culta de la Colonia, sin distinción entre laicos y eclesiásticos, aunque crítica literaria y estética en sus comienzos, perseguía otros fines muy diversos. A través del lenguaje sagrado escuchado por el pueblo se pretendía al fin de cuentas una regeneración del culto católico, una intensificación de la vidaSreligiosa de los fieles. Al sermón barroco que isegún un uquators gnónimo de mediados del XVIII, contenía en cada línea una herejía o un judaísmo ${ }^{1-4}$ se le culpaba iambién de que "en lugar de pulverizar los vicios de los hombres se detiene en describirlos con precisión y elegancia" (Baquíjano) o, lo que era todavía más grave para quienes defendían "la divulgación de las luces", de no enseñar sencillamente al Pueblo las verdades divina sino, como decían Fray Andrés Cuervo y Francisco Ruiz Cano (1770 - 1776) de oscurecerlas con tropos, figuras retóricas o pensamientos ingeniosos que nada tenían que ver con el asunto de la prédica ${ }^{15}$. Qué cristianismo, qué instrucción en los misterios de la verdadera Religión, se preguntaba José Manuel Bermudez, recibían los fieles con aquellos sermones en que se mezclaba inoportunamente lo Sagrado y lo Profano, piezas de mal gusto plagiadas de Plutarco o Cicerón "en que caminaban con paso igual Aristóteles con San Agustín y San Gerónimo: Horacio con los mayores doctores de la Iglesia: las 
Sibilas con los Profetas; el Infierno de Virgilio puesto al lado del que describe el Evangelio, y el Santuario investido de todos los capitanes de Atenas y de Roma" 16.

La mala prédica, es decir la prédica del siglo XVII, venía a ser para los modernistas, enemiga de la Religión, fuente de herejias y de errores perniciosos y susceptible por tanto de ser denunciada no sólo en nombre del buen gusto literario sino también por las normas eternas de moral. Y estas acusaciones morales y religiosas contra el sermón barroco conceptista parecían esgrimidas supletoriamente en la urgencia del combate ideológico sino fuera porque coincidieron con las reiteradas declaraciones de los modernistas de las colonias españolas contra la decadencia del cristianismo. Cuando Bravo de Lagunas condenaba en 1765 las "mentiras piadosas" y Rossi y Rubí en 1792 los dudosos milagros de Tarija, o cuando Rodríguez de Mendoza defendió a un periódico limeño contra los "devotos indiscretos", sus argumentos y posiciones fueron similares a los descritos. Falso milagro, cevoción indiscreta, mentira piadosa, sermón oscuro y artificial, significaban otros tantos obstáculos al cumplimiento de los ideales religiosos. Por oposición, para corregir y desterrar esos excesos, el modernismo escogía como norma segura la simplicidad de las primitivas tradiciones cristianas. El orador sagrado debía tomar ejemplo de los Padres de la Iglesia y de los predicadores que no se habían contaminado de lacorrupción fieraria delssiglo XVII. Los tiempos primitivós, "los tiempos originales situados ,al principio de la historia constituían la meta ideal del modernismo del siglo XVIII. El cristianismo primitivo (predicación, liturgia, dogma) represen. taba la pureza evangélica y la tradición auténtica. Por analogía con ciertas doctrinas políticas si se propugnaba un nuevo lenguaje sagrado era en virtud de este retorno a los orígenes que en el modernismo cobró los prestigios del mito.

7. ¿En qué momento apareció en el Perú esta compleja posición modernista frente a la oratoria sagrada y cuáles fueron las etapas principales de su desarrollo? Algunos autores han sugerido como nombre y fecha iniciales los del jesuita Juan Sánchez y su Sermón de San Lázaro publicado en 1758 (tres años después que los Júbilos de Lima). Durante el propio siglo XVIII fue esa la impresión predominante. Es cierto que Echague sostuvo en 1805 que había sido José Manuel Bermudez quien primero siguió entre nosotros las huellas de los predicadores franceses. Pero si 
se advierte que el testimonio de Echague fuera de su restricción es muy tardío, de principios del siglo XIX, y que el primer sermón que dio cierta celebridad a Bermudez -en las honras fúnebres del Obispo Gorrichateggui- fue posterior al del jesuita Sánchez, el mérito de iniciador revierte a este último como explícitamente lo consignaron en 1792 los redactores de El Mercurio Peruano ${ }^{17}$.

Sánchez, Bermúdez, Ruiz Cano, los nombres son aquí una cuestión secundaria. Lo que interesa es retener no tanto la figura de un posible precursor sino la fecha aproximativa, mediados del siglo XVIII, en que comenzaron las críticas contra la retórica tradicional. Al principio con cierta timidez favoreciendo una reconciliación que tolerase todas las formas de la retórica sagrada, incluyendo desde luego a la retórica modernista. El jesuita Juan Antonio Ribero afirmaba dentro de este ánimo conciliador, todavía en 1749, que la finalidad principal del púlpito era persuadir y convencer a los fieles y que poco importaba para ello el que se escogiesen antiguos o modernos ejemplos de lenguaje. $Y$ si conforme al modernismo indicaba Ribero que en sus prédicas el sacerdote debía atenerse a las Santas Escrituras sin abusar de las citas profanas, decía al mismo tiempo que había siempre de buscarse el placer de los oyentes "pues la censura de los doctos en las oraciones públicas debe conformarse-al parecer de las muchedumbres". Afirmación que en el mismo impreso casi hacía suya el dominicano Manuel-Sánchez Guerrero, lector de Feyjóo y de las Memorias de Treyoux equiencdecíliquenenelos sermones "se varie de Méthodo cuando se varie de Theatro" 18.

Esta moderación fue prontamente reemplazada por una actitud más decidida. La transición no se produjo sin resistencias por parte de los fieles, pues los textos comentados de Ribero y del dominicano Sánchez nos indica que aún a mediados del XVIII subsistían al menos en Lima dos públicos, dos auditorios con gusto opuestos y definidos ${ }^{18 a}$. Como fuera y es asunto que se ha de considerar en otro estudio, a partir de $1750-1760$ y en adelante los predicadores y críticos literarios fueron menos indulgentes. Ya en 1755 el ex-Rector de San Marcos Juan José Marín de Poveda elogiando un sermón de Pedro de Alzugaray (uno de los que aprobó el célebre sermón de San Lázaro) decía: "Dos son las columnas en que se fundaron los maestros de la Oratoria para darle una firme solidez a la delicadeza de este Arte: Sentir y Decir Bien: esto es pensar con rectitud y méthodo y hablar justo y dignamen- 
te". Lo que el antiguo Rector entendía por méthodo y por buen decir es fácil sospecharlo leyendo a su compañero de aprobaciones el jesuita José Bravo de Rivera, enemigo de los circunloquios y largo prólogos, admirador de Francia, "cultísima Nación... Madre aunque no única de las buenas letras" y del saludable contagio de su literatura ${ }^{19}$.

Durante toda la segunda mitad del siglo XVIII, hasia pocos años antes de la Independencia, los intelectuales criollos y españoles continuaron exigiendo la abolición de los antiguos usos literarios. Cada prédica más o menos feliz o sencilla (ambos términos fueron por entonces casi sinónimos) ofrecía una oportunidad para que los aprobantes, admiradores y amigos del autor volvieran a disertar contra el barroco y el conceptismo. Ninguno de esos modernistas se inclinaba ya por una composición amigable como la que habían postulado Sánchez Guerrero y José Bravo de Ribero. "Nóosotros, decía un predicador en las Exequias de Vásquez de Sandoval, nosotros estamos en un tiempo en que ya no se abusa como antes del ingenio y de las palabras; se ha tomado un gusto de escribir más simple, más natural, más corto, más nervioso, más preciso; no se cuida de las palabras sino para exprimir la fuerza de los pensamientos verdaderos, sólidos y concluyentes, para el asunto de que se trata. La erudición en otro tiempo tan fastuosa sólo se muestra cuando es necesario" 20. Todo sacerdote que pretendiera ejercer dignamente el ministerio de la predicación, ministerio alto y augusto "que trasmitía la palabra divina", debería de seguir los nuevos ejemplos de la oratoria sagrada. El estilo de un sermón había de ser natural, desnudo de aliños, cercenado de erudiciones, de esas erudiciones o ignorancias fastuosas que entorpecían la solidez y el desarrollo de los pensamientos verdaderos. El agustino Cuervo - ya citado-y el Prior de Santo Domingo concretaban esta figura o desideratum de la buena oratoria sagrada añadiendo, hacia 1770, que ésta no mezclaba tropos ni figuras al claro desarrollo del discurso, dejando que fueran perceptibles para el oyente las santas máximas de la Iglesia ${ }^{21}$. El sermón era un diálogo entre el sacerdote y los fieles; o, mejor aún, el sacerdote representaba al Cristo-Maestro de los Evangelios y su lenguaje como el de Cristo debía de acercarse a la llaneza de las conversaciones de familia. El predicador era un apóstol y no un artista (Echague 1782) obsesionado por el adorno profano e inútil. En el Elogio escrito por Baquíjano en favor de su pariente Calatayud, 
en las aprobaciones que publicaron en 1818 los amigos de Mández Lachica, se repitieron y glosaron las mismas ideas ${ }^{22}$.

\section{Afrancesamiento y neologismo.}

8. ¿La nueva oratoria sagrada, y en general el modernismo, se identificó con el afrancesamiento? Si y no a la vez. De un lado los propios autores y críticos peruanos del siglo XVIII declaraban sin temor que había sido Francia el primer país en exigir la renovación de los gustos artísticos. Las obras de Massillón, Bourdalue, Flechier y muchos otros se leyeron por entonces en su originales y traducciones. Y una comparación atenta encontraría que buena porción de la predicación criolla se nutrió durante esa época, no solamente en sus temas sino también en el estilo y en el vocabulario, de los modelos franceses ${ }^{23}$. Pero aquellos mismos que imitaron o plagiaron esos textos se resistieron, siquiera teóricamente, a una simple copia irreflexiva. Su intención fue aprovechar la lección francesa en beneficio de las auténticas tradiciones españolas (es decir las primitivas o anieriores al barroco) a fin de que un nuevo humanismo surgiese de aquel encueniro. Francia simbolizaba, es cierto, la cultura moderna - la "Madre, aunque no única de las buenas letras" - pero a titulo casual y temporario; pues todos los pueblos podían-alcanzar el mismo nivel de desarrollo y quizás hasta uno superior. La España ilustrada, auxiliada por Francia, pretendia devenir con cierta ingerisidad no francesa sino más española, más próxima a sí misma. Que lo consiguiera o no y que insistiendo en el valor de lo propio y de lo nacional ("amar al país") otorgara una justificación y un instrumento al separatismo americano es cuestión aparte.

Hubo sin duda durante el siglo XVIII un afrancesamiento en la Península, en el Perú y en todos los países de la cultura occidental; pero en alguna medida ese afrancesamiento que sus propios actores prefirieron llamar "modernismo", fue un afrancesamiento involuntario. En las doctrinas políticas y en las ciencias naturales o en el caso concreto de las ideas e inquietudes lingüísticas, no ha de olvidarse por otra parte que hubo durante el siglo XVIII una contradicción frecuente entre los diversos objetivos culturales en juego; contradicción paralela y simultánea a otra entre esas aspiraciones y sus resultados, y que la época no puede reducirse a uno de esos aspectos sino a la tensión dialéctica que 
convocándolos permitió su desarrollo. El afrancesado pudo ser al mismo tiempo un nacionalista rabioso y el escritor modernista, a pesar de sus injurias contra el barroco, continuar usando el propio estilo que aborrecía.

Estas complejidades y aparentes contradiciones del proceso cultural del siglo XVIII, explican porque fue muy débil entre los modernistas peruanos -afrancesados a medias sinembargo- la corriente favorable a los extranjerismos de lenguaje, tan peligrosos a su entender como el abuso de metáforas o la oscuridad del estilo. Si para regenerar la oratoria sagrada se recomendó el ejemplo literario francés, no fue por afrancesar el idioma nacional sino, exclusivamente, para combatir el barroco. Entre los pocos defensores del neologismo, y en particular de los galicismos, opuestos a este nacionalismo lingüístico, estuvo José Baquíjano y Carrillo, demasiado amigo de novedades, defensor un día del País, o Amante del País y al mismo tiempo partidario de los filósofos europeos que despreciaban al Nuevo Mundo. En su Elogio a Jáuregui (1781) Baquíjano sostuvo, interpretando al padre Isla, a don Luis de Cueto y a Fenslón, que todo pueblo se hallaba autorizado al uso de aquellas voces que le fueran precisas sin demandar el origen de las mismas. Las palabras según Baquíjano, iextualmente, no eran más que sonidos de los cuales podían hacerse signos arbitrarios del pensamiento "'En, si continuaba, no tienen ningún valor y son tanto del pueblo que las da como del que las recibe. ¿Qué importa que "unar palabra sea nacida en nuestro país o que nos venga de un país extranjero?" 2.4.

Contra el pudor académico y la xenofobia lingüística, Baquíjano recordaba con cierta ironía que el castellano históricamente no venía a ser más que una mezcla de extranjerismos, es decir de voces derivadas del griego, latín, fenicio y arábigo. Por aplicación retroactiva, un nacionalismo consecuente debía concluir en el absurdo de negar al castellano todo derecho de existencia.

9. Ningún otro escritor peruano del siglo XVIII coincidió con las opiniones de Baquíjano. Algunos como ese purista desesperado que fue el Conde de las Torres, huésped de Feyjóo, llegaron a tolerar las voces extranjeras, los galicismos, en la conversación íntima, "manejadas con gracia y moderación", pero no más. Y cuando el infortunado Miguel de Valdivieso olvidó esta prudencia del buen decir, el irrascible Conde de las Torres fustigó sus galicismos como si fueran injuria gravísima a la Nación española : 
"Cuando el Nativo Idioma, en que se habla, tiene copia de voces para expresar los Conceptos es injuria tomarlas del Extraño. La hermosura del estilo nace de la propiedad de las voces; no de la introducción de las Exiranjeras, cuya práctica es especie de deslealtad al Patrio Idioma. Abundante materia tienes de este discurso en la Crítica Pluma benedictina de nuestra España..." 2 .

La misma intransigencia profesó el Marqués de Soto Florido; no sólo en los Júbilos de Lima -donde su posición fue más bien moderada- sino también en sus elogios a Bermúdez y a Rodríguez Tena (1770-1776): Cada pueblo recordó Soto Florido, con palabras de David Hume, tenía la obligación de desarrollar sus propias artes y su propia lengua sin convertirse en "esclavo de sus vecinos" ". Incluso los más sospechosos de afrancesados cuidaron de aclarar sus opiniones y alardearon de firmes defensores del castellano, aunque paradójicamente utilizaran para ello de vez en cuando a los propios autores franceses. Así Irigoyen (1789) quien aprobando la Oración Fúnebre a Carlos III del oratoriano Amil y Feyióo, decía que en los sermones corrientes había de imitarse a Bossuet, Mascarón y Flechier, pero preservando siempre, advertía, la pureza del idioma, "distante de aquel extragado gusto y ridícula manía de hablar el francés en castellano" 27 . Y en nombre de un autor francés, Francisco Xavier Echaguee(1782) aconsejó a los predicadores perugnos que buscasen un estilos propio y original, de modo que ya no el vocabulario sino el ritmo de la composición estuviesen libres de la sombra del plagio ${ }^{28}$.

\section{El Latín y el Castellano.}

10. El tercer enemigo del castellano moderno, a renglón seguido del barroco y del neologismo francés era el latín. Aquí el pensamiento ilustrado tropezó con las resistencias más decididas. El latín había sido durante siglos el idioma litúrgico y científico de Europa, el instrumento de su unidad cultural a través de las barreras lingüísticas. Juzgado como el lenguaje sabio, el paradigma de todos los lenguajes humanos, no habían faltado antes del siglo XVIII autores que propusieran una latinización creciente del español para sacar a la lengua vulgar -según dijo El Lunarejo"de los rincones de su hispanismo" 29. Frente a estos latinistas 
pertinaces que se avergonzaban de hablar su propio idioma surgieron desde el Renacimiento los apologistas y defensores de las llamadas lenguas vulgares (Bembo, Du Bellay, Valdez, Cristóbal de Villalón, Pedro Mexía, Pedro Simón Abril...); pero el siglo XVII olvidó o desdeñó estos alegatos y al introducirse con los Borbones el pensamiento moderno en España y sus colonias, el Latín continuaba siendo el lenguaje universitario de los intelectuales, al menos nominalmente, pues en la práctica, como ha recordado Carerter, pocos lo conocían y usaban correctamente ${ }^{30}$.

Mientras el Latín fuera la única lengua oficial del saber, el programa de la Ilustración europea no podía ser cumplido en España y menos aún en el Perú. La divulgación de las luces, la aparente democratización de la cultura, sólo era posible gracias al simultáneo desarrollo de las lenguas vulgares que todos hablaban. El Latín sólo era un lenguaje minoritario. ¿Cómo hacer conocer la Verdad a los hombres en otro idioma que el suyo? Si los conservadores argumentaban que existían ciertos conocimientos dañinos o peligrosos para la mayoría de los hombres, los discípulos del racionalismo moderno replicaban que el Bien era inseparable de la Verdad, que no existía conflicto entre ambos y que la educación del género humano suponía el imperio de la virtud. En segundo lugar, un idioma apartado del ejercicio de las ciencias, como era el caso del castellano desde el siglo XVI, sucumbía fatalmento en la vulgaridad" se empobfecía y afeaba hasta" la postración; confiriendo entonces, paradójicamente, una apariencia de razón, a posteriori, a las propias medidas que habían causado su desgracia. Poco se hubiera logrado si después de derrotar a los conceptistas y barrocos y de preservar a la lengua nacional del extranjerismo, se toleraba que aquella lengua convalesciente fuese excluída de la cultura para que sobreviviese como un lenguaje doméstico. Después de conquistar el púlpito, el castellano modernizado debía de conquistar las universidades; ninguna disciplina le sería entonces extraña, desde la filosofía hasta las ciencias naturales y el Derecho. Bueno en la casa de Dios lo era también en la ciudad de los hombres. Así, por una lógica inmantente al planteamiento ideológico de la Ilustración, al programa de reformas estéticas sugerido por Ruiz Cano, Juan Sánchez, Bermúdez, elc. ... hubo de suceder en el Perú la crítica de la latinidad de las cien- 
cias, del esoterismo del pensamiento y en definitiva de los últimos obstáculos que impedían el renacimiento del Castellano como idioma moderno.

Los síntomas de este segundo desenvolvimiento de las inquietudes lingüísticas modernas aparecieron en el Perú tardíamente, pues durante todo el siglo XVIII no he comprobado otros que los implícitos en aquellos textos que aplaudiendo los nuevos gustos literarios, reprochaban el abuso de las citas clásicas u oponían las excelencias del castellano, a las del francés o a las de cualquier otro idioma, sin mencionar concretamente al latín ${ }^{31}$.

11. La primera obra dedicada a este asunto fue "El Uso de la Lengua Vulgar en el estudio de las Ciencias..." (492 ps.; Lima 1806) escrita por Ramón Olaguer Feliú y ofrecida al Virrey Abascal por un alumno del Convictorio de San Carlos ${ }^{32}$. El libro fue preparado en pocos días ("corriendo la pluma a la par que la prensa") y su autor no hizo más que recoger las opiniones de Mayans, Sampere, Jovellanos, Feyjóo y otros. Lo cual no le avergonzaba.

"... sin rezelo de que me llamen copista o me censuren de fastidiosa la repetición de citas y de textos: por quanto mi ánimo no es hacer de erudito con ridícula pedantería, sino recoger los fundamentos de una práctica literaria, tan desatendida de la preocupación común. En lo qual sigo la máxima de ciento escritor que elegía demosirar unacosa con razones buenas aunque no fuesen suyas "orge Puccinelli Converso"

Olaguer Feliú añadía ufanamente que su estudio sino original, al menos era del todo nuevo en el Perú y que no había merecido hasta entonces la atención de nuestros escritores. Creía sinembargo que las Universidades indianas, y entre ellas la limeña, podían comprender la importancia del tema con mayor facilidad que las academias españolas. Pues no existían entre nosotros las mismas viejas preocupaciones y usos inveterados que aquejaban a la enseñanza peninsular. Aprovechando el buen juicio de Sampere y quizás a El Mercurio Peruano que comentó el hecho en uno de sus tomos, Feliú recordaba que mientras la Universidad de Salamanca había llegado a prohibir el Curso de Muchembrook, en el Perú se reformaba los programas de estudio y se adoptaba públicamente las filosofías de Newton y Descartes.

Ya estas alusiones indican bien que las preocupaciones de Olaguer Feliú fueron más de índole pedagógica y científica que es- 
trictamente lingüística; y que, por otra parte, la rivalidad entre el Latín y los idiomas nativos, sólo constituía un episodio en la larga contienda contra el escolasticismo del siglo XVII. Para Olaguer Feliú los defensores del Castellano eran al mismo tiempo partidarios de la filosofía moderna, mientras que los lainistas encarnaban las desacreditadas ideas y prejuicios del aristotelismo.

En la Parte Primera de su libro, dividida en cuatro capítulos, Feliú quiso demostrar que el estudio de las ciencias en idioma vulgar favorecía de un lado su aprendizaje y del otro el mejoramiento del castellano y de las diversas disciplinas científicas. A estas páginas sigu:eron otras tituladas "El Estudio de las ciencias en idioma vulgar considerada en la práctica", que comentaremos muy brevemente pues repiten y glosan los mismos temas de la primera sección.

En ninguna de esas dos partes Feliú negó que fuera necesario y útil estudiar el Latín; pero insistió en que los idiomas vulgares constituían el medio natural de comunicación en el ejercicio de las ciencias. ¿En qué otro idioma que el suyo - diario y vulgar en su tiempo- habían transmitido su saber los caldeos, los egipciọs, los griegos $\mathrm{y}$, desde luego, los romanos?. Las primeras nociones de una disciplina científica - sin considerar el idioma empleadoofrecían de por sí sobradas dificultades a los principiantes. Cada ciencia poseía sus propias voces, un lenguaje técnico privativo y todo el esfuerzo inicial rdel aprendizaje seohallaboodirigido, según había indicado Condillac, a conocer ese vocabulario. Quienes para todo ello aconsejaban el uso del Latín añadían a estas dificultades intrínsecas, el estorbo de una lengua extraña, mal conocida, teniendo paradójicamente a la mano, a la boca, otra que les pertenecía por nacimiento. Así, los estudiantes de ciencias obligados a emplear el Latín oficiaban siempre, quisiéranlo o no, de traductores, oficio el más penoso según prudentemente había dicho Sampere. Ejercitaban por tanto la memoria, no la reflexión y agotados y aburridos de esta complicación innecesaria terminaban por abandonar las ciencias y preferir aquellos estudios, pocos por desgracia, en que sólo les era exigido el conocimiento de su propio idioma.

El propio Feliú había podido confirmar prácticamente la verdad de estas afirmaciones. Autorizado por Rodríguez de Mendoza había enseñado la Física en el Convictorio de San Carlos, sirvién- 
dose del Diciconario de Brisson traducido al Castellano. Comprobó que sus alumnos aprovechaban más en este curso que en los de Lógica, Etica y Metafísica, "en cuyo estudio ha sido preciso ceder a las costumbres"; es decir, no emplear el idioma nativo. Si se permitiera la adopción del Castellano en la enseñanza, decía Olaguer Feliú, no tendríamos que lamentar la necedad y la ignorancia ni la cultura superficial e inútil de quiénes egresaban de nuestras academias; podríase instruir a los estudiantes en disciplinas modernas e indispensables para la vida social (Historia, patria, Economía, Física, Geografía) que eran hasta entonces incompatibles con los métodos escolares vigentes.

"...tendríamos en los colegios lugar oportuno de aprender cosas de la mayor importancia, y necesarias en el día más que nunca, a todo hombre de luces; como son además de los fundamentos de nuestra Religión santa y su celestial doctrina, la Historia sagrada y profana, y en particular la nacional: los elementos previos de la cronología y de la Geografía, así antigua como moderna: el principio, mutaciones y estado presente del mundo físico, político y moral: la Economía pública; con otras muchas nociones que ahora se descuidan... De donde resultaría que no saliésemos de los colegios como sucede al presente; que después de haber concluído un estudio por la mayor parte inútil... quedamos, como dice Petronio $\sin$ los conocimientos indispensables para los usos de la vida; empero tan orgullosos como necios, porque niosiquiera seimosida luzede do que nos falta por saber".

12. Pero las ventajas que venían de emplear el Castellano en las ciencias no sólo eran de carácter pedagógico. La vida de las ciencias y la vida de las lenguas vulgares, dependían, según Feliú, la una de la otra. Este era un hecho comprobable históricamente y no una simple hipótesis. "Todos los siglos nos presentan pruebas de que siempre florecieron las ciencias a proporción de que se han estudiado en lengua vulgar; y esto no es una paradoxa sino una observación fundada, sino me engaño en la historia de la literatura". Si durante la dominación árabe, por ejemplo, la ciencia española superó a la de los otros países europeos, fue porque estos últimos, después de haber abandonado el Latín no habían entretanto perfeccionado su propia lengua. Los árabes, al contrario, poseían ya un idioma que les servía por igual para la reflexión filosófica que para los negocios familiares. 
Feliú proporcionó otras pruebas de esta solidaridad entre la Ciencia y el Lenguaje, examinando el desarrollo de la cultura europea desde la Edad Media (término que empleó) y durante los siglos XVI y XVII hasta su florecimiento en el XVIII. No comentaré por extenso esas páginas, en todas las cuales Feliú reiteró su oposición al latín y al escolasticismo. A través de esa exposición histórica, la época decisiva tanto desde el punto de vista lingüístico como del científico era desde luego el Siglo de las Luces. Feliú admitía que éste no había sido fecundo en genios y obras magistrales, pero no vacilaba sin embargo en calificarlo en su conjunto como una "revolución literaria". La Cultura moderna de allí surgida podía ufanarse legítimamente de haber impuesto un nuevo régimen de ideas y un tipo de sensibilidad más acorde con la naturaleza humana y con las necesidades de la vida social. Y tan prodigiosos adelantos habían sido efecto y causa a la vez de la libertad concedida a las lenguas nacionales que pudieron así reemplazar ventajosamente al latín. En francés, por ejemplo, un buen francés moderno - un idioma lan vivo y vulgar como el Castellano- habían escrito D'Alambert, Fontenelle, Buffon y Bayle.

Complemento de esta argumentación fue para Feliú insistir en que si las ciencias progresaban a medida que se generalizaba en ellas los idiomas vulgares; éstos, a su vez, sólo podían desarrollarse gracias a ese mismó contacto fecundo. as este tema dedicó Feliú todo el capítulo III de do Parte Primera de su libro. "Las Lenguas, decía repitiendo a Hervás, son pobres o ricas de palabras, bárbaras o civiles en sus expresiones, a proporción de la variedad de las ciencias que en ellas se escriben". Cuando se les emplea exclusivamente en el uso diario y familiar, decaen y se corrompen. Tal el Castellano. Pocos lo estudiaban con ahinco. La mayoría se había persuadido de que era superfluo conocer sus reglas o dedicarle otra atención que la muy escasa que se concede a los coloquios domésticos. Si por fortuna alguien contrariaba estos perjuicios, pocos le alentaban. Este había sido el triste castigo sufrido en Lima por el maestro Bernardino Ruiz. Ruiz había intentado enseñar a sus discípulos la Gramática Castellana al mismo tiempo que el Latín, pero muchos padres se habían quejado amargamente de este proyecto; no quisieron confiarle a sus hijos y dijeron que aquello "era hacerles perder el tiempo en estudiar lo que todos sabemos naturalmente". Las consecuencias de 
este desprecio hacia el propio idioma se advertían de inmediato. Con el tiempo los jóvenes iniciados mediocremenie en los rudimentos del Latín y sin la más leve sospecha de lo que fuese su propia lengua, terminaban por latinizar mal y hablar peor el Castellano. Y cuando ésto se evitaba, veníase a caer en otro vicio no menos reprensibles: Deseosos de instruirse y no encontrando buenos libros científicos ni en Latín ni en Castellano, acudían a los autores franceses, confundían las voces propias con las ajenas - ya que no conocían bien las suyas ni la disposición o genio de su lenguay al fin de cuentas plagaban su Castellano de la "peste perniciosísima" de los galicismos.

Contra esos peligros Olaguer Feliú reiteraba sin cansancio sus primeras afirmaciones. Hagamos del Castellano un lenguaje científico y moderno; restablezcamos la comunicación entre la palabra y el pensamiento reflexivo. Pensar bien para llegar a Decir bien; puesto que ninguna lengua vive de los sonidos sino de las significaciones.

"Porque la lengua que hablamos no se aprende sino por el uso y nadie sabe de ella más cie lo que pertenece a la significación de las ideas que tiene y de las cosas de que se trata.. De este principio se deduce necesariamente de que no hablará jamás con propiedad y cultura el que sólo ejercite su lengua en ideas vulgares; yabcontrafio, quien la use en las cosas de la ciencia: y que según la extensión de los conocimientos será más copiosa y expresiva"

13. La Parte Segunda de su obra la dedicó Feliú a ampliar todos los puntos de vista resumidos, demostrando particularmente no ya las ventajas teóricas del ejercicio científico del Castellano, sino las posibilidades prácticas de su aplicación. No se trataba de reemplazar violentamente un método por otro ni de darse prisa en suprimer una costumbre, sino de averiguar, como aconsejaba Pluche en su Mecánica de las Lenguas, si en la variación había o no que temer algún peligro.

¿Sería el Castellano tan apto como el latín para expresar las verdades científicas? Feliú no parecía satisfecho con las respuestas que él mismo se había suministrado. Insistió. Contra los que decían que toda lengua vulgar, comprendiendo al Castellano, era incompatible con la gravedad de las Ciencias, Olaguer afirmaba que ningún idioma era de por sí culto o vulgar. "Que si porque 
a nuestra lengua llamamos vulgar -copiaba de Fray Luis de León- se imagina que no podemos escribir en ella sino vulgar y bajamente, es grandísimo error: que Platón escribía no vulgarmente ni cosas vulgares en su lengua vulgar; y no menos ni levantadamente las escribió Cicerón en su lengua que era vulgar en su tiempo". Si empleáramos el Castellano, como hicieron los escolásticos, en sutilezas y banalidades, por cierto que nuestro lenguaje sería mezquino y del todo indigno de las Ciencias. Pero el mismo defecto había de encontrarse en los malos latinistas o en los que pensando en latín, pensaban mal o pensaban poco. El castellano podía, al igual que no importa qué lengua, expresar con justicia lo más alto, lo más difícil y secreto del universo, incluyendo las verdades racionales científicas.

De otro lado, la discusión sobre el mayor derecho de las lenguas modernas en relación con las disciplinas científicas, era una discusión secundaria. Pues de hecho en esas lenguas, vituperadas por los latinistas, se habian escrito las principales obras cieniíficas modernas. La única excepción, según Feliú, era la teología; lo cual carecía de importancia a su juicio pues ya el Abate Andrés había dicho "que todo lo que mira a la disciplina eclesiástica ocupa el día de hoy un ínfimo lugar entre los estudios en aprecio". En el dominio de esta propia Teología, además, tan compasivamente juzgada, se habían ya publicado textos en idiomas vulgares, en castellano, como el traducido por Pouget que según un "sabio teólogbolimeño" bástabà para saben mucho más de lo que se enseñaba en los Colegios.

Demostrada la aptitud general de las lenguas vulgares para servir de instrumento científico, sus adversarios rearguían sin embargo que debía darse la preferencia al latín porque sólo una lengua privativa y de acceso difícil a la mayoría de los hombres, preservaba a la verdad de ser profanada por el Vulgo. Contra esta concepción aristocrática y esotérica de la cultura, Feliú oponía el repertorio de la Ilustración sobre la divulgación de las luces. En primer lugar el calificativo de "vulgares" convenía a muchos de los que hablaban y leían latín. "Porque cierto hay muchísimos que no habiendo estudiado otra cosa, se confunden con el vulgo; para los quales, cualquier libro de ciencias en latín es lo mismo que los de romance para los demás idiotas: y aún peor, porque en sus manos corren todavía mayor peligro, por quanto errarán precisamente equivocando el sentido de las cosas que per- 
cibieran con facilidad en la lengua propia". En consecuencia, el argumento de la profanación conducía no a generalizar el latín y restringir el uso del Castellano, sino a la creación absurda de una multitud de lenguajes particulares, tantos como hubiera disciplinas científicas, a fin de que sólo los iniciados pudieran entender las Ciencias.

\begin{abstract}
"Y aún sería mejor que cada uno tuviera su propia lengua aparte y que el teólogo hablase la suya y otra el filósofo y otra el jurista y otra el médico: porque la teología no da al teólogo inteligencia de las matemáticas ni el médico entenderá de teología más que otro cual. quiera".
\end{abstract}

Además, y esta era razón primera contra la cultura aristocrática y minoritaria, ningún hombre decía Olaguer Feliú posee mejor derecho que otra a la Verdad. Las ciencias (más útiles que la labranza y que el oro de las minas) debían hallarse a disposición de quien tuviera capacidad para comprenderlas. "A la verdad y al conocimiento todos tenemos derecho, no son patrimonio de unos pocos que a sí mismos se nombran sus privilegiados y exclusivos dueños".

14. Con algunas precauciones Feliú aplicó este mismo planteamiento al dominio religioso. ¿El Castellano -útil en las ciencias- serviría también para expresar los misterios sagrados? Los defensores del Latín sostenían que en este dóminio el idioma vulgar era aún más peligroso que en el orden científico. Feliú concedió a estas pretensiones mayor atención que a todas las otras. $Y$ las expuso puntualmente, según su costumbre, a fin de replicarlas sin asomo de duda. Los latinistas decían defender el decoro de la Religión. El Latín impedía, según ellos, que la mala inteligencia del pueblo profanase las verdades eternas de la Revelación. Por esa causa, Pío IV había vedado las ediciones bíblicas en lengua vulgar, así como toda clase de controversias sobre asuntos de religión entre herejes y católicos. "De donde conclưyen que la Ciencia de la Relión no debe tratarse sino en el mismo idioma que tiene autorizado la Iglesia: y que es apartarse de sus intenciones el promover su estudio... en lengua que proporcione su inteligencia a todo género de personas".

De ninguno de estos hechos, en sí innegables, podía concluírse sin embargo, según Feliú, que la Iglesia intentase ocultar a? 
pueblo cristiano la noticia de sus verdades. Atribuirle esa intención era audaz calumnia como había dicho Benedicto XIV. Feliú recordaba diversos textos canónicos en favor suyo y afirmaba que las providencias particulares que por justas causas había dictado la Iglesia, no servían de regla prohibitiva general. Lo probaba, entre otros, el hecho de que si bien se había, por ejemplo, prohibido en 1660 un Misal en lengua francesa, la Inquisición española había tolerado en 1782 las versiones vulgares de la Biblia. La Iglesia no tiene preferencia por idioma alguno, salvo en la liturgia. Dios quiso que el uso de las Escrituras fuese común a todos y las compuso con palabras llanísimas y en idioma vulgar. "Quién hizo las tres lenguas principales, citaba al Papa Juan VIII, a saber la hebrea, la griega y la latina, también fue el que crió todas las demás para loor y gloria suya".

En cuanto al peligro que para las almas sencillas podía venir de estudiar su Religión, Feliú respondía con dos argumentos. En primer lugar, de acuerdo a ese temor debía también de impedirse que el pueblo conociera las Leyes civiles, a fin de que tampoco supiera qué infracciones y delitos no debía cometer. Paradoja y contradicción que por sí solas, si no hubiera otras buenas razones, demostraba el absurdo en que incurrían los enemigos de los idiomas vulgares y de la divulgación de las luces. Por otra parte, en segundo término, Oloquer Feliú se negaba a crer que de un co. nocimiento, cualquiera que. él fuese, podía proceder algún mal. De la ignorancia, sí, delgprejuicio, pero noldel saber. Al igual que los otros modernistas peruanos, Feliú identificaba optimistamente el Bien y la Verdad y buscaba un modo de reconciliar lo racional con lo profano. Cristiano instruído y cristiano verdadero devenían entonces sinónimos para él. Y admitiendo que se reservasen algunas nociones complicadas y profundas, para que sólo fuesen conocidos por los doctos, exigía que todos los cristianos estudiasen y meditasen su Religión, de acuerdo a sus diversos grados de aptitud. Se observaría entonces un mejoramiento en las costumbres públicas y una práctica más sincera y depurada de las virtudes cristianas.

"Pero sea de esto lo que quieran: lo cierto es que si la Religión fuese mejor conocida de los fieles se vería más respetada. Por que no es posible ocuparse en su estudio sin que se eleve el entendimiento y el cora.. zón quede arrebatado al contemplar el sistema admira. 
ble de sus principios y la luminosa oscuridad de sus dogmas, y las obras sobrenaiurales de Dios... De este nismo esiudio saca también el cristiano sólidos principios que le sirvan de segura guía para no extraviarse dexándose arrasirar de las falsas máximas en orden a las cosiumbres, las supersticiones y el abuso de las cosas sagradas" 34 .

15. El largo discurso de Olaguer Feliú desvanecía con estas últimas reflexiones los inconvenientes más graves que los latinistas aducían contra el uso religioso y científico de las lenguas vulgares. Sin embargo Feliú creyó necesario escribir aún unas cuantas páginas más. La discusión de argumentos sólo constituía uno de los aspectos de la contienda y quizás en clefinitiva, el de menor importancia. Aunque se convenciera a un latinista de la falsedad de sus opiniones, era muy improbable que éste renunciara voluntariamente a seguir sosteniéndolas. Porque su menosprecio por los idiomas vulgares no era exclusiva consecuencia de un "error lógico", de un raciocinio defectuoso. Con más frecuencia de lo deseable el hombre no aciuaba de acuerdo a sus juicios - falsos o verdaderos- sino a decisiones adoptadas de antemano, al margen de cualquier discernimiento, es decir sometiéndose al prejuicio, a la preocupación, a la opinión en fin, que no venía a ser sino un saber dudoso.

Aquellas manifestaciones de la irracionalidad humana no constituían fenómenos puramente psicológicos e individuales (hábitos, predominio de las pasiones, etc....) sino también colectivos: las costumbres. Antes de examinar con auxilio de la Razón un problema cualquiera -el de comparar por ejemplo los idiomas vulgares y el Latín - el hombre consultaba los usos ya establecidos; acudía a la tradición, buena o mala, en busca de normas. Y así porque desde muy antiguo el Latín había sido considerada como la única lengua culta, y sin pensar seriamente acerca de sus ventajas o defectos, muchos la seguían defendiendo. "Así lo hicieron nuestros mayores, dicen, así se ha hecho siempre; luego es bueno y debe continuar: que sería presunción nuestra modificar lo que ello entablaron". Esta costumbre que no se gobernaba por principios sino por imitación (textualmente), este miedo servil a las innovaciones que esclavizaba a la Razón, según Rollin, surgía ante los modernistas como el más temible adversario. 
Todavía resta otro (obstáculo) que parece más insuperable a saber la costumbre o mejor diremos la acihesión tenaz a ciertas prácticas que se admiten sin examen y se conservan por capricho. Que los demás obstáculos ceden fácilmente, viéndose desamparados de la razón cuyo apoyo buscaban: mas como la costumbre no la escucha, porque no se gobierna por principios sino por imitación; va pasando de unos a otros, aunque sea perniciosa y se forifica, sea porque éstos conciban bueno quanto practicaron nuestros mayores, sea porque no osen aquellos confesar el vicio aunque lo conozcan".

¿Cómo atajar esas costumbres? Feliú, como su siglo, no encontró una respuesta adecuada. Por su misma naturaleza (gobernada por la imitación) la costumbre repugnaba a la vocación racionalista de los intelectuales modernos, que sin embargo, no podían dejar de reconocer la necesidad de su existencia 0 , mejor dicho, su carácter forzoso. Toda iniciativa, todo ímpetu de reforma, pasado el primer momento de euforia, languidecía y se disciplinaba en instituciones que, al fin de cuentas, sólo venían a ser organizaciones públicas de las costumbres. El propio modernismo había de tener las suyas. Ambicionar un mundo dirigido por el pensamiento, sin hábitos, sin costumbres, sin sentidos y sin imaginación, de puros espíritus razonadores, hubiera sido una utopía herética cuando no un absurdo. La Hlustración no pretendía crear un nuevo ser que sustituyera al hombre, la obra más perfecta de la Creación cristiana. Había que aceptar a ese hombre tal como era originalmente, tal, como por ejemplo, lo había descrito Ruiz Cano en su Júbilos de Lima; y a lo más corregir sus extravícs, restablecer el equilibrio natural. Por tanto en vez de emprender un quimérico esfuerzo para suprimir las costumbres había que situarlas en el justo lugar que les correspondía en la vida social. Sujetas a variación, buenas o malas, según las circunstancias - como había dicho Rodríguez de Mendoza, maestro de Feliúnuestro criterio para seleccionarlas sería el de la necesidad de cada época. A las viejas costumbres, las nuevas, aunque no pudiésemos definir con toda claridad en qué consistía la necesidad aludida "Un sistema literario o político que hoy es perjudicial, pudo ser útil $\mathrm{y}$ aun necesario en tiempos anteriores; $\mathrm{y}$ el que fue antes odioso y detestable puede hacerse muy ventajoso después". Invocando este relativismo histórico Feliú reiteraba su exhortación: el latín fue útil en su tiempo; ahora lo es el Castellano. 
16. Otras observaciones acerca de esta preocupación lingüística del siglo XVIII. Se dijo en las primeras páginas de este trabajo que esa preocupación fue en el Perú el privilegio de un pequeño círculo. Su zona de influencia se resiringía a las ciudades ( $y$ a Lima como su foco principal) y dentro de ellas a ciertos institutos, como el Convictorio Carolino, dedicados casi del todo a los criollos y peninsulares de las clases altas. Europeo en sus orígenes, el pensamiento moderno no perdió este carácter en la América Española a pesar de sus eventuales alianzas con el criollismo. En el orden lingüístico por ejemplo —desde Ruiz Cano hasta Feliú- el intelectual modernista, aislado geográfica y socialmente del resto del país, sólo tomó en cuenta su lenguaje, el de, la cátedra y el púlpito, sin averiguar los problemas inmediatos del habla y sin continuar la tradición (siglos XVI y XVII) de los expertos en lenguas indígenas.

Prueba de este desinterés es la decadencia de los estudios sobre el quechua y el aymara hablados por la mayoría de los habitantes del Perú. El siglo XVIII fue el siglo en que se redactó el Ollantay, pero también el siglo en que fue suprimida la cátedra de quechua en la Universidad de San Marcos. Es cierto que Llano Zapata equiparó el quechua al idioma latino y que el tarmeño José Manuel Bermúdez escribió un Elogio de esa lengua y quiso que la Sociedad de Amantes del País, fundada en Lima, fuese para el quechua lo que lar Academia de Crusca para "el Toscano y las de Francia y España para sus respectivos idiomas ${ }^{35}$. Pero en términos generales, el balance fue negativo y nada ofrece de comparable al esfuerzo de los lingüistas misioneros de los siglos XVI y XVII. $\mathrm{Si}$ exceptuamos los estudios sobre dialectos selváticos, emprendidos por franciscanos y jesuitas (La Montaña amazónica reemplazaba entonces a la Sierra andina como tierra de catequesis), muy poco más hubo: el Diccionario quechua-aymara de Marcos Vega, el Catecismo quiteño de Romero, el Vocabulario de Juan de Velasco... A no ser que por piedad se añadan las simples reimpresiones como la Gramática de Torres Rubio (1700) y los trabajos de Mercier (1760) o el Catecismo del VI Concilio Limense (1773) simple copia del ordenado en $1583^{36}$. Esta superficialidad e indiferencia no fueron por cierto compensadas ni corregidas desde el extranjero ni por el entusiasmo de Hervás y Panduro o Buffon ni por la pésima Gramática de Godin des Odonais o por el vocabulario compa- 
rativo de La Condamine; y menos aún por las pocas páginas que sobre el Quechua escribió, antes de la Revolución francesa el jansenista Grégoire.

17. En lo que toca a las corrupciones o variantes locales del español, la actitud de los modernistas peruanos fue la misma. Y su única excusa podría ser que al respecto no existía entre nosotros tradición alguna. Pues la pequeña lista de voces del idioma "xacarando" que consignó El Lunarejo no eran precisamente peruanas ${ }^{37}$, como tampoco nos concerrían los "Valencianismos o defectos en que los valencianos incurren de ordinario hablando castellano", copia manuscrita que guardaba la antigua Biblioteca de Lima ${ }^{38}$. Solamente dos autores, ninguno de ellos criollo, estudiaron aunque fuera de paso los usos diarios del lenguaje español y las modificaciones que había sufrido en el Perú al contacto de una realidad distinta a la peninsular: Uno de ellos fue el presbítero Antonio Pereyra, residente en la diócesis de Arequipa y el otro Don José Rossi y Rubí, animador de El Mercurio Peruano. Pereyra en su Noticia de Arequipa (1816) incluyó unos cuantos "nombres provinciales" señalando con un astérico y una $\mathrm{V}$ los que provenían de la lengua india (quechua) y los que eran usados por el vulgo. En cuanto a Rossi -en cuyo periódico se publicaron unas voces de mineralogía - tenía en preparación un trabajo sobre temas similares que nadie ha visto nunca ${ }^{39}$.

De menor importåncia todavía quelos mencionados es el Libro de Diversos Asuntos escrito por un vecino de Arequipa entre 1819 y 1827 en el que se insertaron algunas sentencias populares. Ningún otro testimonio puede ser recogido ya que la Colección de Adagios de Llano Zapata no pasó de cotejar las frases latinas con los refranes leídos en Hernán Núñez, Blasco de Garay, Martín Caro y otros ${ }^{40}$. 


\section{NOTAS BIBLIOGRAFICAS}

(1) Vargas Ugarte "La Elocuencia Sagrada en el Perú en los siglos XVII y XVIII, Lima 1942. Vargas Ugarte dedica la mayor parte de su ensayo a lcs oradores de fines del XVII y principios del XVIII.

Para el estudio de las ideas lingüisticas en España, véase: CarreterLázaro "Las Ideas Lingüísticas en España durante el siglo XVIII", Madrid 1949; Menéndez y Pelayo, Marcelino "Iistoria de las Ideas Estéticas en España". Tomo III. Siglo XVIII Espasa - Buenos Aires, 1943.

(2) De otra parte la actitud moderna frente al lenguaje estuvo condicionada no solamente por una necesidad instrumental y científica sino también, según ha de verse, por las exigencias de un nuevo tipo de sensibilidad, anterior, como tal, a tcda reflexión.

(3) Sin que esas implicaciones ideológicas fueran claramente advertidas a veces por aquellos mismos que postulaban un "nuevo lenguaje".

(4) En este sentido todo el pensamiento moderno, incluyendo sus prolongaciones en las idcologias políticas de la Independencia, constituyó entre nosotros un fenómeno colonial. "Los modernistas peruanos del XVIII pretendieron "poner el Perú a la hora de Europa", accidentalizarlo. Aún en aquellos momentes en que lucharon contra algunas formas de la colonización española. El propio criollismo, en esta perspectiva, estuvo más cerca del sustrato cultural europeo que del sustrato cultural indigena.

(5) Véase ps. 296 y ss. de este trabajo

(6) Ruiz Cano y Galiano, Francisco, "Júbilos de Lima en la dedicación de su Santa Iglesia Catedral...", Lima 1755. Ruiz Cano murió en 1792 ("Libro de Cuentas, apuntes de inter'és y personales del Chantre Dr. Don José Manuel Bermúdez". Archivo del Cabildo Eclesiástico de Lima). El inventario de su biblioteca en mi estudio "Las Bibliotecas Peruanas del siglo XVIII". Lima 1960 (Archivos de Grados de la Facultad de Letras de San Marcos).

(7) Ruiz Cano Op. Cit. Sobre esta noción del hombre como conflicto a la cual se alude más adelante en el texto, véase también un pasaje de la "Oración Fúnebre... de la R. M. María Antonia de San Joseph..." (Lima 1733) escrita por el mercedario Calatayud: "Lleno el espíritu de falsos prejuicios y dominado el corazón por las pasiones, no es posible curar con sólo los medios naturales, la corrupción del hombre. En él se forma un círculo perpetuo de iluciones, en que el entendimiento y voluntad mutuamente se causan la infeción, y el desorden. Si procuramos ilustrar la razón, el apetito intercepta la luz y la desvía: si queremos corregir las afecciones de este previene la razón, y la viciada, en lugar de reglarlas, las promueve y las irrita. La alma piensa; pero con dependencia de la carne inficcionada, con sugeción a las pasiones rebeldes, con una relación necesaria a los objetos corpóreos que inducen las más veces al engaño.

(8) Ruiz Cano Op. Cit.

(9) Ruiz Cano Op., Cit.: "Hasta ahora son deslucimiento de su hermosura (en Europa) muchas antiguas Catedrales, formadas según las groseras y confusas ideas de las medidas Góthicas. Aquellos bárbaros del Norte que en el siglo quinto destruyeron el Imperio Romano no contaron entre sus menores triunfos, haver hecho dominante el gusto irregular de su arquitectura. Con el vencimiento de Roma quedó cautiva la razón. Aun la Italia que adornada de tantos monumentos de un gusto fino y delicado, no pudo impedir tan fatales progresos: dexo su arquitectura autorizada por la antigüedad, por el aplauso y por la posesión; adoptando uno bárbara, irregular, confusa y poco agradable. 
Pero ella enmendó en el décimo sexto esta falta; y puso a LIMA, que en aquel siglo se construía en estado de aprovecharse de sus luchas". Y más adelante añade: "Ya no se puede ver sin enfado la multitud de alhiños, la confusión, la afectación y la pequeñez de las molduras góthicas".

Este menosprecio por el Gótico fue muy frecuente en el Perú del siglo XVIII. Todavía a principios del XIX, Oláguer Feliú (180ô) decía: "Esto a decir verdad (el respeto de las antiguas costumbres) me parece lo mismo que si nos obstinásemos en conservar las costumbres y edificios góthicos, después del gusto refinado de este siglo, por la razón de que asi lo usaron nuestros abuclos en tiempo de Wamba o de Witiza". (10) La principal atracción de esta música, arquitectura de los sonidos, consistía en la introducción de la palabra, de un significado conceptual: "Pero todos los primores de que es capaz la Música Instrumental no huvieran podido sostener por mucho tiempo esta violencia a no entrar el Canto en refuerzo de su agrado... Es necesario que la Música imite, como todas las demás Bellas Artes, las imágenes y sentimientos que ocupan el espíritu o que ella se confiese indigna de un carácter que merece tan de justicia. Es necesario finalmente que los hombres no se contenten con escuchar voces que no se animan con algún pensamiento, o que ellos renuncien a todos los derechos que les da lo racional" Ruiz Cano Op. Cit.

(11) Porque todas las artes eran consideradas como una sola y provenian y se desarrollaban a partir de los mismos principios, las críticas al estilo literario barroco aparecieron frecuentemente unidas durante el siglo XVIII a la defensa de la arquitectura neoclásica. Véanse la estrofa X del "Poema Epico en... la Magnífica Renovación... de San Francisco"; L,ima 1805. Y las estrofas IX a XII de" ...El Vergel Dominicano", Lima 1807 escrito por Casimiro Novajas.

(12) Acerca del barroco y del conceptismo literarios: Carreter Op. Cit. Menéndez. Pelayo Op. Cit. Tomo III; Menéndez Pidal, Ramón "Castilla, la Tradición, el Idioma" Buenos Aires 1943; Vargas Ugarte Op. Cit. También entre otras fuentes de los siglos XVII y XVIII y para una caracterización de sus respectivos estilos: a) Fuente, Francisco de la "De lo bueno lo mejor" Lima 1693; con una crítica de los oradores lacónicos y de quienes en el púlpito afectabán hablar el francés cn castellano; b) Bermúdez de la Torre, Pedro, Jose "Oración Informativa..." Lima 1699. Definiendo sus gustos pictóricos: "Y como a la Pintura la hacen gozar en más virtualidad no tanto los matices que la encienden y los golpes de luz que la retocan, como aquella valiente resistencia de. sombras que en graves pinceladas la retiran; assi también a la felicidad iluminan opuestos accidentes"; c) Velasco Martín de "Arte de Sermones para Saber hazerlos" Madrid 1677. Con reglas y consejos de retórica en algo similares - sin que ello sulponga influencia- a los de Vico en su "De nostri Temnoris studiorum ratione" (Traducción de Firnesto Grassi, Santiago de Chile, sin fecha); d) Castro, Ignacio de "Relación de la Fundación de la Audiencia del Cuzco". Donde decía de Peralta: "Nuestra América nos ha dado en Lima muchas relaciones de fiestas. -El insigne Don Pedro de Peralta podría dar reglas de ellas a todo el mundo. El inventó ese modo decir raro, sentencioso y tan fértil, que parece se le atrodellaban las nobles imágenes; pero quizás este modo no ha prolongado más su existencia que la de su inventor; con él parece que nació, y con él se scpultó. Le era tan familiar que jamás dexaba de destilarle de la pluma y se le había hecho como una especie de monotonía... Se carga la mano en alusiones que no todos enticnden o no tienen presentes el objeto del reclamo: se usan voces que piden por instantes diccionarios: se afecta de no llamar a las cosas por sus nombres, y olvidados los Autores del sicum sicum scapham nos introducen en un idioma copioso qual es el Espa- 
ñol, lo que sólo podría pasar en el escaso"; e) Chrisóstomo Logiofilo "Carta Escrita a la Sociedad sobre los progresos de la Oratoria en nuestra patria 'El Mercurio Peruano (1791-1794) Tomo V f. 198; f) Ruiz, Bernardino "Comṕendio de Retórica en forma de diálogo para el uso de la juventud" Lima 1813. Este es un pésimo plagio o resumen y mezcla de las más diversas ideas. Ruiz distinguió al declamador del orador; a las tesis (cuestiones infinitas) de las hipótesis (cuestiones finitas) y señaló tres géneros de oratoria: judicial, deliberativa y demostrativa, a la cual correspondían otros tantos tiempos verbales. Los autores que recomendó Ruiz fueron todos de la antigüedad clásica, a excepción de Luis Vives. Su Compendio elogiaba al estilo Sublime y condenaba al Asiático o sea "aquel estilo pomposo y difuso en que se dice con muchas palabras; de su estilo deberás huir si eres prudente".

(13) Explícitamente lo dijo Fray Joaquín Suero en su Aprobación al Elogio Fúnebre de Vásquez de Sandoval (Lima 1786): "Hasta las mismas aprobaciones pueden hacerse útiles, proponiendo en ellas las reglas de la más perfecta Oratoria y eloquencia: de manera que con sólo mudarles el título, se convertirán en discursos o disertaciones sabias".

(14) "Consulta de Libros..." Mss. Biblioteca de la Universidad de San Marcos; sin fecha ni nombre de autor, pero indudablemente escrito en el siglo XVIII.

(15) Cuervo, Fray Andrés. Aprobación a Freyre, Fray José "Sermón de las exequias del siervo de Dios, el M. R. P. M. Fr. Gregorio de Mendoza..." Lima 1770: "El estilo es natural y sin mezcla de Tropos y Figuras Rethoricos, pretendiendo solamente el Autor hacer perceptibles al comun de los mortales las virtudes del siervo de Dios sin afectación alguna y sin acudir a aquellos adornos del arte conque se revisten los asuntos más descarnados y lánguidos".

Ruiz Cano, Francisco; en su Aprobación a Rodríguez Tena, Luis "Oración Fúnebre que en las exequias de N S S P Clemente XIV..." Lima 1776: "Hállase trabajada esta preciosa materia de enseñanza en un estilo propio, puro y magestuoso, qual convenía a su grabedad... No sobrecargado con copia excesiva de expresiones figuradas... cuyo abuso frecuente muestra una importuna afectación de ciencia: causa sequedad en el Discurso: oscurece el Idioma patrio: y el que en el púlpito debiera ser el más perceptible, se hacesparticular, y como para comunicarse sólo entre sí mismos los predicadores; sin participación del Pueblo, que ni posee las Lenguas Originales de los Libros Santos, ni en sus modos de explicarse descubre con facilidad las alusiones de que pende, su inteligencia. No herizado en fin por decirlo así, de los pensamientos ingeniosos que acumularon los antiguos panegyristas... cuyos elogios sobre todo género de acciones virtuosas están ya prevenidos, $y$ sin otro costo que transcribirlo no cuidando de la justicia de su aplicación..."

La cita de Baquíjano en su Parecer a Calatayud, Fray Cipriano Gerónimo "Oración Fúnebre... en las solemnes exequias de la R M María Antonia de San Joseph..." Lima 1783.

El autor del sermón era primo de Baquíjano por el linaje de Garcés y perteneció a la orden mercedaria. Otro hermano suyo, Luis, ingresó o quiso ingresar a la Buena Muerte (Arch. Buena Muerte 00007), mientras que Francisco ocupaba por esa misma época la mayordomía del hospital de la Caridad. El primer Calatayud que vino al Perú fue familiar del Virrey Castellfuerte y casó con doña Francisca de Borda. De Gerónimo, el mercedario, hay dos necrologías en $\mathrm{El}$ Investigador del Perú (Nos. 46 y $59 ; 15$ y 28 de Agpsto de 1814 , respectivamente). Otras noticias en los documentos del Archivo Nacional del Perú: a) Poder para testar de Don Gerónimo de Calatayud; Secc. Protocolos Notariales; Portalanza 1739, f. 100; b) Testamento de Doña Francisca de Borda; Idem 1746; f. 192; c) Superior Gobierno, legajo 12 (1791- 
1792) "Autos que siguen los Diputados del Rl. Hospital de la Caridad contra el Mayordomo sobre varios cargos".

(16) Bermúdez, José Manuel. Aprobación a la Oración Fúnebre mencionada en la nota anterior. Bermúdez incluyó en esta aprobación suya una breve historia de la elocuencia cristiana, desde su decadencia en los siglos XVI y XVII hasta su renovación a principios del XVIII. Esta renovación se identificaba para él con la tradición de los padres de la Iglesia, el destierro de la erudición profana y del escolasticismo y con "la solidez del lenguaje, lo justo de los pensamientos, lo sano de la doctrina".

Bermúdez, colaborador de El Mercurio Peruano, era un afrancesado convicto; en esta misma aprobación suya elogió en Calatayud su estilo "acuté, ornaté, vehementer... y no grosero, despacible y frío".

Noticias biográficas de Bermúdez en un impreso de dos hojas, sin fecha ni título que comienza: "M I y Ven. Dean y Cabifdo. El Doctor Don José Manuel Bermúdez: Cura Propio de la Ciudad de León de Huánuco..." y en un curioso Libro de apuntes personales escrito por el propio Bermúdez y que guarda el Cabildo Eclesiástico de Lima. Nació en Tarma el 5 de enero de 1742, comenzó sus estudios de latín a los 9 años, tres después vino a Lima e ingresó en el Colegio de San Martín el año de 1757. Concluyó los estudios de Arte en 1759 y se doctoró en Teología en 1762. Opositor a la Cátedra de Maestro de las Sentencias en 1764; ordenado de Sacerdote en 1768. Su primera prédica la hizo en 1770 en la ciudad de Tarma y antes de su célebre oración de 1776. en homenaje a Gorrichategui había subido al púlpito tres veces. Según sus cuentas había escrito y pronunciado 21 sermones. Fue Cura durante 16 años, desde 1789 . En 1803 se le nombró Racionero de Lima, en 1805 Secretario del Cabildo.

(17) Sánchez, Juan "Sermón que en la Missa de Acción de Gracias por la reedificación o nueva construcción total del Hospital de San Lázaro de la Ciudad de Lima Predicó..." Lima 1758. El libro tuvo las aprobaciones de Miguel Sanz de Valdivieso y de Pedro de Alzugaray $(+1764)$. Alzugaray criticó la erudición sin sentido que convertía los discursos en "complexo hacinado de noticias"; la elocuencia sagrada, según él, no debía ser considerada como un teatro de vanidades ni mendigar adornos a los escritores profanos y menos aủn a la mitología. Método y Razón eran sus requisitos principales. El ejemplo del jesuíta Sánchez influyó, según El Mercurio Peruano en el tacneño Ignacio de Castro ("Elogio histórico Fúnebre del doctor Ignacio de Castro" Mercurio Peruano, Tomo VI, f. 36): "Este ilustre expatriado que fue el primero que enseñó en Lima a hablar con acierto en los Púlpitos sagrados, es el autor del Panegírico del estreno de San Lázaro y de la Oración fúnebre del señor Fernando VI que después de algunos años se leen con agrado y se citan con entusiasmo no sólo en América sino también en Europa".

La referencia de Echague a Bermúdez en su aprobación al sermón pronunciado por este último: "Fama Póstuma del excelentísimo Señor... Don Juan Domingo Gonzales de la Reguera..." Lima 1805. E1 sermón de Bermúdez a que se alude en el texto se tituló: "Oración fúnebre que en las exequias del Ilustrísimo Señor D. Agustín de Gorrichategui dignísimo Obispo de la Santa Iglesia del Cuzco dixo el doctor Don Joseph Manuel Bermudez" Lima 1776. No fue el primero de los suyos (cf. nota anterior) pero sí con el que inició su fama de orador moderno.

Otras referencias a Sánchez en el mismo Mercurio Peruano, Tomo V, 198 ("Carta Escrita sobre los progresos de la Oratoria en nuestra Patria") donde también se elogia a Miguel Sanz de Valdivieso, como representante de la elocuencia civil. 
(18) Aprobaciones del jesuita Juan Antonio de Ribera y de Fray Manuel Sánchez Guerrero al "Sermón Panegírico Moral que el Octavario de la Concepción... de María Santísima... predicó... Juan Ântonio de Tagle y Bracho..." Lima 1749.

(18 a) Todavía en 1783 Calatayud (Op. Cit.) podia quejarse de la actitud del público asistente a los sermones. Muchos fieles esperaban, decía, una larga relación de maravillas curiosas: 'La mayor parte de las gentes que llenan los Templos quando en ellos se celebran Exequias a los Siervos de Dios, que han dado buen olor de sus virtudes no concurren... con un espíritu de Religión; sino de curiosos: ni se proponen oir virtudes que muevan la voluntad a la imitación; sino gracias y dines extraordinarios que arrebaten con la admiración el espiritu: en fin no se procura el fruto sino la diversión... Para prevenir pues el juicio y la expectación de los concurrentes, se dixó en el Exordio que el Discurso no sería una historia perpetua de milagros, revelaciones y profesías; sino una relación seguida de virtudes, exemplos y santas operaciones". Sin duda que las declaraciones de Calatayud 1) estuvieron condicionadas por la modestia de su tema; y que 2) no contienen referencia explícita al estilo literario que se empleaba en los sermones. Sirven sin embargo para identificar a dos tipos de elocuencia, con sus públicos respectivos: La prédica modernista caracterizada por la sobriedad del tema (que suponia la sobriedad del estilo) y por subrayar el carácter pedagógico del Sermón Cristiano. Y la prédica barroca, preocupada del adorno, de solicitar la admiración más que de convencer y para la cual el Sermón era, sobre todo, un espectáculo. Sin recurrir a una fácil antinomia entre pedagogía y estética, podría no obstante decirse que para el predicador modernista el púlpito fue una $\mathrm{Ca}$ tedra -en el sentido más estricto - a la cual subía para enseñar; mientras que el predicador barroco sometía y condicionaba esta preocupación magisterial a su intención de distraer y regocijar a sus oyentes. Oposición desde luego relativa puesto que todo Sermón -modernista - barroco- constituía un espectáculo y una distración en la Colonia; y porque a su vez, la enseñanza asimismo se cumplía en todo caso. De lo que se trata aquí es de determinar el grado de cada intención.

Al margen de estas consideraciones he de añadir - pues debió ser advertido en el texto- que si los modernistas se interesaron en el $\mathrm{Pe}$ rú por reformar la oratoria sagrada, fue, en parte, debido a la influencia y a la divulgación que supone toda literatura oral. Nosotros, decía Huitzinga, lectores de periódicos, podemos difícilmente imaginar el poder de la palabra escuchada. Los hombres del siglo XVIII lo conocían bien. El Sermón suministraba un modelo de lenguaje más accesible al gran público urbano semi-culto que el libro impreso. Feyjóo lo dijo -indirectamente al elogiar la conversación- en su "Balanza de Astrea (Teatro Crítico; Tomo III, Discurso XI; Madrid 1729): "Pero mejor que los mejores libros es la buena conversación. La enseñanza que se comunica por medio de la voz es natural; la de la escritura artificial; aquella animada, está muerta; por consiguiente, aquella eficaz y activa, está lánguida. La lengua escribe en el alma como la mano en el papel. Lo que se oye es el primer traslado que se saca de la mente del que se instruye; y lo que se lee es ya copia de copia". Pero acerca de este asunto y de su tema complementario: la lectura y sus formas durante la Colonia, reservo la exposición para un próximo estudio.

(19) Aprobaciones de Marín de Poveda y de José Bravo de Rivero a la "Oración panegírica a El Santo Rey Don Fernando de Castílla..." Lima 1755 predicada por Pedro de Alzugaray.

Marín de Poveda fue acusado por sus enemigos de padecer la lepra y separado de sus funciones eclesiásticas. Siguióse juicio con intervención del Protomedicato limeño. La causa llegó a España de donde vinọ Real Cédula (Aranjuez 31 Mayo 1755) rehabilitando a Marín de 

Poveda. Archivo del Cabildo Eclesiástico de Lima "Cédulas Reales y
otros papeles" Tomo I.

(20) Cita que de Fenelón hizo Fray Bernardo Rueda en su "Relación de las Exequias que a la Memoria del Rmo.... Francisco Xavier Vásquez... celebró la provincia del Perú..." incluida como apéndice al "Elogio Fúnebre..." escrito por Fray Felipe Castán, Lima 1786. En el mismo impreso véase la Aprobación de Fray Joaquín Suero.

(21) Véanse su aprobación y dedicatoria a Freyre y Lazo, Fray José "Sermón de las exequias del siervo de Dios, el M R P M Fr. Gregorio de Mendoza..." Lima 1770.

(22) Méndez Lachica, Tomás "Panegírico del patriarca San Felipe Neri..." Lima 1818. Opiniones y elogios, entre otros, de José de Arriz y de Sánchez Carrión. "La presente obra, dice uno de ellos, se ha considerado por los inteligentes como un modelo de aquella elocuencia varonil y magestuosa, en que cumpliendo con el destino de la oratoria sagrada, se hacen gustar al auditorio frutos de edificación y doctrina en vez de presentarles únicamente flores y bellezas de ingenio".

Noticias sobre el autor y su familia en los siguientes documentos del Archivo Nacional del Perú: a) Sección protocolos notariales; Luis Tenorio 1792, f. 1023; b) Sección Gobierno, leg. 14 (1796-1798); y en el Archivo histórico del Ministerio de Hacienda, Colección Santa María 0016 y 00167.

(23) Un desarrollo más amplio de este tema del "afrancesamiento" en mi estudio de próxima publicación sobre el pensamiento moderno peruano del siglo XVIII.

(24) Baquíjano y Carrillo, José "Elogio del excelentísimo Señor Don Agustín de jauregui..." Lima 1781. Reproducido en el Boletín del Museo Bolivariano, Lima 1929, n. 12.

La posición de Baquíjano frente al idioma merecería un estudio especial. Frente al latín, por ejemplo, aunque creyendo como los de su tiempo en las ventajas de un uso científico del castellano, conservó no obstante cierta reserva respetuosa. Así en su informe como Protector de los Naturales sobre la causa seguida al cacique Tambohuacso (Lima, 22 de agosto de 1780) justificó un pasaje en latín, diciendo: "Sus palabras se trascribirán en latín para que no pierdan la fuerza de su original". Lo cual puede, por otra parte, entenderse como restricción del valor de las traducciones. Cf. Eguiguren, Luis Antonio "Guerra Separatista del Perú 1777-1780" Lima 1942.

Más moderado que Baquíjano, otro discípulo de Gorriochategui, el tacneño Ignacio de Castro decía en su "Relación de la Fundación de la Audiencia del Cuzco..." Madrid 1795. "Al caso se citó alli la bella crítica del Abad Desfontaines, o sátira de las locuciones nuevas que contuvo a muchos escritores que ya iban a precipitarse en el vicio común del neologismo. Pues en verdad es intolerable la afectación de algunos quo no quieren servirse sino de voces nuevas, o distintas de las que el uso común autoriza; cuando aquellas sólo deben adaptarse si hay escasez de las que son propias del idioma, según el prudente precepto de Horacio". Y en otra ocasión: "Jesús. Recójaseme esta voz francesa que se me ha deslizado de la pluma por la mala habituación conque tantos pedantes nos oprimen con sus galicismos".

La polémica acerca de los neologismos se desvió en el Perú alguna vez hacia la de la menor o mayor autoridad de la Academia de la Lengua. Cierto "liberalismo" aplicado al idioma, llevó a los mismos enemigos de las voces nuevas y extranjeras a no conceder un carácter definitivo e inapelable a los juicios del Diccionario Académico. El Investigador por ejemplo - adversario de toda centralización del poderdecía ( $N o$ 65, 3 setiembre 1814) que la Academia debía tomar en cuenta la tradición de los padres de la lengua y que era preferible estar equivocado con un poeta que estar de acuerdo con un académico. Adviér- 
tase que esa apelación a los Padres de la Lengua, correspondía en todo a la exaltación de los Padres de la Iglesia en las discusiones teológicas.

En ambos casos la tradición era puesta al servicio de las pretensiones renovadoras del modernismo y no de los conservadores.

(25) Zeballos, Juan José, Conde de las Torres "Diálogo Crítico sobre la Oración Panegírica que dixo el Doct. Don Miguel de Valdivieso y Torrejón..." Segunda Impresión, Madrid 1764. La primera, anónima y prohibida por las autoridades, se tituló "Diálogo entre un bedel de la Universidad de Lima y el R P Fray N Lector de Artes..." Trascribo parte de ese diálogo:

"Lector.- Maneras no es castellano: esto es barbarismo, y por ser tomado del francés, se llama Galicismo. Es un notable vicio: tanto mayor cuanto es más dura y dissonante la expresión, como Maneras.

Bedel.- Pues ya le he oido siempre en Castellano.

Lect. Lo havrás oido por las Aberturas que tienen a los lados las Ropas Mugeriles. Y manera, en singular, por el modo conque se hace alguna cosa, pero no por el trato político de las gentes, que es por lo que aquí se pone y lo que significa en francés.

Bed. Perdoneme VP, que a hombres bien entendidos lo he oído en el mismo sentido, que dice VP que significa en francés.

Lect. No lo dudo: Porque en la Conversación tan lexos está de ser vicio el uso de algunas voces extranjeras, que antes la amenizan.... No es lo mismo en las obras del estilo Sublime, donde no hoy licencia para apartarse de lo mejor".

(26) Ruiz Cano, Francisco: a) "Júbilos de Lima...": "Pero hubiera sido agravio de nuestro romance no emplearlo también en la expresión de los mismos sentimientos. El idioma francés, que no aventaja al nuestra en alguna de aquellas calidades, que contribuyen a la perfección de una lengua, no sufrió sino una increíble resistencia, ver decorado con inscripciones latinas, un Arco de Triunfo que se erigió en París en honor de la Memoria de Luis el Grande" Párrafo en el que hay que retener tanto la referencia al latin y la equivalencia entre el francés y el castellano, como la utilización de un ejemplo extranjero (francés) para favorecer lo nacional (el idioma castellano).

b) Aprobación a la "Oración Funebre... de Agustín de Gorrichategui..." pronunciada por José Manuel Bermúdez, Lima 1776.

"Vemos además de ello, no sin dolor, que nuestro idioma degenera sensiblemente. Que nacen cada día voces y locuciones que desconocieron del todo nuestros mayores. Que se supone en el pueblo otro genio, otra necesidad, otro caracter y aún otra instrucción, pues que se le haōa en énfasis y en expresiones tomadas a la letra del original y primeras versiones de los Libros Santos. Que despreciada finalmente la abundante fecundidad del lenguaje español, se le pretende sujetar a una monotonía insípida y poco conforme a su nativa majestad y ele-

c) Aprobación a la "Oración Fúnebre que en las exequias de $\mathrm{N}$

SS P Clemente XIV ... dixo... Luis Rodriguez Tena, Lima 1776. propio, puro y magestuoso, qual convenia a su gravedad. No ofuscado con voces de un Idioma Extrangero, que trasladas al nuestro son, a lo menos inútiles: por más que pretenda autorizarlas el uso; como si fuera preciso pagar esta fea servidumbre a una Nación extraña, que por los grandes modelos de eloquencia sagrada que ha producido se reputa como única maestra en ese arte".

(27) Irigoyen, José, de Aprobación a Amil y Feyjóo, Vicente de "Oración fúnebre del señor Don Carlos III..." Lima 1790.

(28) Echague, Francisco Xavier. Aprobación a Cano, Fray Francisco "Uración fúnebre dicha en las exequias funerales que la Casa de Observancia de Predicadores de Chile hizo a su difunto fundador... Manuel de Acuña..." Lima 1782. 
(29) Espinoza Medrano, El Lunarejo "Apologético.... de D. Luis de Góngora..." 29 edición, Lima 1694, ps. 59, 74, 78, 81; "Dezir Faria que es yerro usar en nuestro idioma lo que es propio del latino es error suyo, pues si esto es aliño de la Poesía Latina, no es tan inepta, baxa o incapaz nuestra lengua, que desmerezca... aquellas galas". Góngora sacó al Castellano de su hispanismo, habia hecho esa lengua de corta, sublime; de balbuciente, fecunda; de estéril, opulenta; de encogida, audaz; de bárbara, culta. Lo cual al entender de este mestizo cuzqueño era regresar a los origenes pues primitivamente habían sido los latinos quienes imitaron de los españoles la bizarría del decir, hasta obtener aquel lenguaje que como decia Erasmo no es de quien habla con elocuencia sino de quien truena con asombro.

El ejemplar que he consultado pertenece a Luis Loayza; en algunas de sus páginas hay curiosas anotaciones manuscritas del siglo XVIII contra el escolasticismo.

(30) Carreter Op. Cit.; con bibliografia a pie de página. También Lapesa, Rafael "Historia de la Lengua Española" Madrid 1942.

Acerca de la actitud del Estado español frente al uso universitario del latín véanse las disposiciones regias de Felipe II (1598), Fernando VI (1753), Carlos III $(1771 ; 1773)$, Carlos IV (1798) en el Tomo III, Libro VIII, Título IV, Ley II de la Novísima Recopilación. Cito de la redición de París, 1846.

(31) En lo referente al uso del Castellano en los estudios teológicos podría mencionarse como un lejano antecedente-de las opinfones de Olaguer Feliú, las de Peralta en su Pasión y Triunfo de Cristo (Lima 1738). Sin ocuparse de la contienda entre el Latín y las lenguas vulgares, Peralta sostuvo que incluso los laicos -con información y formación suficiente- podían ocuparse de examinar las Sagradas Escritures. Desdeñaba así el argumento de la "vulgarización peligrosa" que los latinistas esgrimían para excluir al Castellano del dominio de las ciencias y de la Religión. Decía: "Las Sagradas Escritüras son Templos Mentales que tienen, para todos los que entran a sacrificar el estudio, abiertas las puertas de la inteligencia y verdaderamente no es el que los cultiva el que los penetra, sino los Padres que lo gulan. $Y$ en fin nunca puede ser osadia lo que es salvación ni extrañeza lo que puede ser ternura".

Más explícito el testimonio de Ignacio de Castro en"su Segunda Disertación... sobre la Concepción de la Virgen..." (Lima 1784). En particular ps. 47 y ss., 272 y ss.; en que trata del latín y las lenguas vulgares en relación con la. Teología.

Podría mencionarse otros testimonios de fines del siglo XVIII y principios del XIX, todos ellos en defensa del Castellano. Por ejemplo el de Agustín de Landaburu y Belzunce en su "Ensayo sobre los primeros fundamentos de las bellas letras" (Lima 1785) que muy al final de su interrogatorio decía: "Mientras se consagran tantos cuidados al conocimiento de las lenguas extrañas, es preciso no olvidarse de la propia, solicitando el conocimiento de sus voces". $Y$, por último El Invesvestigador - años después que Feliú- condenando el abuso del latín en las recetas médicas (No 21; 21 de Julio 1814): "Yo no se qué peculiar encanto tenga una receta escrita en latín; ¿Por ventura adquiere algún grado más de perfección el remedio recetado en Latín; alivia más pronto al enfermo...? ¿De dónde viene señor Robespierre, que las demás naciones receten en su lengua nativa y los españoles en lengua extranjera? ¿Sabrán menos latín que los españoles?"

(32) Ramón Olaguer Fcliú "El uso de la Lengua Vulgar en el estudio de las Ciencias... que dedica al Exmo. Señor D. Joseph Fernando de Abascal... D. Manuel Sáenz de Tejada A nombre del Convictorio de San Carlos por el D. D. Ramón Olaguer Feliú..." Lima 1806 Natural de Ceuta y Diputado y Secretario de las Cortes de Cádiz, Feliú estuvo preso - culpable de liberalismo- en el castillo de Benas- 
que. Aficionado a las matemáticas y a las ciencias naturales, de él decía un impreso limeño que aplicaba el compás, los métodos geométricos y las fórmulas algebraicas a las ideas políticas. Cf. a) "Discursos pronunciados en las Cortes generales de la Nación..." Reimpresión limeña sin fecha ni indicación de la imprenta; b) Mendiburu, Manuel de "Diccionario Histórico Biográfico" Lima 1876; c) Eguiguren, Luis Antonio "Diccionario Histórico Cronológico de... la Universidad de San Marcos..." Tomo I, Lima 1940.

(33) Feliú Op. Cit. citando a Hervás y Panduro.

(34) Olaguer Feliú Op. Cit. En las ps. 380-387, Felió añadió a estos argumentos una defensa del Laico y de su posición dentro de la Iglesia. Siguiendo a Muratori sostuvo que el término o calificativo de "Lego" (por ignorante) podía convenir fuese a un clérigo, fuese a un seglar. Señaló las vinculaciones entre las palabras clérigo, literato y docto, demostrando que habían sido aplicadas a todo hombre de estudio sin reparar en que perteneciese o no al estado eclesiástico. En consecuencia, las prohibiciones contra el Lego no lo eran contra el Laico o Seglar sino contra el ignorante. Y también podía ser ignorante $-y$ en materia religiosa - un hombre de Iglesia.

(35) Llano Zapata, José Eusebio "Preliminar y Cartas que preceden al Tomo I de las Memorias Histórico Physicas, Críticas Apologéti'cas de la América Meridional" Cádiz 1759.

Bermúdez, José Manuel "Discurso sobre la Utilidad e importancia de la Lengua General del Perú" Mercurio Peruano, T'omo IX, fs. 176 y ss.

Llano Zapata afirmó que tanto el latín como el quechua eran indispensables en la formación cultural de los peruanos: como introducción, respectivamente, a los idiomas modernos y a las lenguas e historia aborígenes del país.

Bermúdez dominaba no sólo el quechua corrompido de la sierra central -el quechua chinchaysuyo- sino también el más perfecto y pulido del Cuzco. Fue Bermúdez, junto con Crespo y quizás con el español Cerdán, y con Millán de Aguirre, de los pocos Amantes del País que demostró un franco e ntusiasmo por la cultura prehispánica. ¿O hay que mencionar también a Pastor de Larrinaga con sus malos versos sobre los Incas, al autor del articulo sobreslos yaravíes, a Unanue con anotaciones pasajeras sobre la cultura indígena y a Egaña que solicitó en nombre de todos ellos planos e informaciones sobre las antiguallas del Perú? Dejemos para otra ocasión discutir el asunto.

En su afán de procurar, según decía, el renacimiento de una literatura quechua, Bermúdez, que no fue un purista intransigente, admitió que pudieran incorporarse al idioma aborigen aquellos neologismos que lo enriquecieran sin entorpecer su genio y sintaxis. El entusiasmo de Bermúdez por el quechua lo hizo gran lector de Hervás a quien elogió y de los jesuitas expulsos ("nuestros hermanos expatriados") aunque lamentaba que éstos no hubiesen escrito sobre el Perú obras semejantes a las de Clavijero, Molina, Morel y otros.

Sobre la influencia de Hervás en los grupos intelectuales peruanos de fines del XVIII, véase "Carta Escrita a la Sociedad por un Distinguido Americano residente en la Corte de Madrid" (carta del 14 de diciembre 1791). Mercurio Peruano. Tomo V, fs, 172 y ss. El americano era Santiago-Concha que sostuvo correspondencia con Hervás.

El desinterés a que aludimos en el texto fue, sobre todo, un fenómeno costeño, más aún limeño. Lo cual es mucho decir dada la indisputada capitalidad cultural de Lima durante la Colonia. En el Cuzco al contrario, los criollos, hasta los más aristocráticos, se enorgullecían del idioma aborigen. Manuel Quimper (Descripción Sucinta y en Globo de San Carlos de Puno" Madrid 1822) lo comprueba: "Tienen mucha pasión a su quechua y a la. Imarae que en toda la sierra a los es- 
pañoles hijos de ellas les es muy predilecto, particularmente al sexo femenino del primer rango; que en la sociedad de etiqueta hay una jerigonza entre ellas que llama la atención de los hombres e incomodo a los europeos y en donde más se advierte es en las ciudades de Cuzco y La Paz". Prueba de este arraigo de la antigua lengua es, por otra parte la existencia de un movimiento literario quechua, tal como lo deseaba Bermúdez. Se escribieron entonces multitud de comedias, poesías y dramas en quechua, y se llegó incluso, pocos años después de los que estudiamos, a traducir del francés al quechua una obra de Racine, la Phedra. Cf. Pacheco Zegarra, Gabino "Ollantai" París 1874.

(30) Rivet y Créqui de Montfort. "Bibliographie Quechua et Aymará" París 1951-1956. Porras Barrenechea, Raúl. "Los Quechuistas coloniales" El Comercio, julio 28, 29 y 30 de 1948; "Los Quechuistas del Perú' Mercurio Peruano, Diciembre de 1950; "Él Ollantay y Antonio Valdez". Actas del Congreso de Peruanistas de 1951 ; y sus prólogos a la Gramática y al Vocabulario de Fray Domingo de Santo Tomás (Lima 1951) y al Vocabulario de Diego González Holguín (Lima 1952).

(37) Espinosa Medrano, El Lunarejo Op. Cit. La cita es cortísima y servía al Lunarejo para justificar una lengua secreta y privativa para la poesía y los hombres cultos, como existía otra del vulgo delincuente: "Más dicha tienen los picaros en su idioma xacarando, que llaman trena a la cárcel, xaque al valiente, Coillón al pregonero, gurapas a las galeras, mosca al dinero, trongas a las rameras y finibusteras ala horca". (Subsisten hoy - desaparecidos la horca, el pregonero y las galeras - mosca,, pero no trongas) ¿Ni cómo esperar más de quien en todo su libro no puso más nota de color local que la de comparar las manzanas de oro al color de los auquénidos andinos?

Tampoco interesaron durante el siglo XVIII los dialectos africanos que hablaban los esclavos de la Costa. Miguel de Olabarrieta Medrano ("Recuerdo de las Obligaciones del Ministerio Apostólico en la Cura de Almas" Lima 1714) fijó al respecto la posición de la Iglesia y la que entonces por lo general predominaba: Según él los Curas estaban obligados a conocer la lengua indígena pero no la de los negros. $Y$ los españoles ni una ni la otra. "De otra suerte se siguiera que también fué ra necesario supiesen bien los curas de españoles en Lima todas las lenguas de los negros de Guinea, pues son muchos más los que en la ciudad y el campo "sonlfeligreses suyos que noljos indios que están mezclados con los españoles en sus feligresías: unos y otros, negros e indios tienen mucha comunicación con los españoles; y tienden a darse entender en su media lengua a lo español, por ser este idioma el común y vulgar entre todos".

(38) Palma, Ricardo "Catálogo del Salón América..." Lima 1891.

(39) Pereyra y Ruiz, Antonio "Noticia de la Muy Noble y muy Leal Ciudad de Arequipa..." Copia fotostática en la Biblioteca Nacional de Lima (X985. $41 \mathrm{P} 43$ ) del original existente en la Biblioteca de Tenerife. Una presentación de la obra. En Lostanau, Alejandro "El desconocido manuscrito de Pereyra y Ruiz..." Fénix, Segundo Semestre 1946.

Sobre Rossi y Rubi, véase El Mercurio Peruano Tomo II, f. 123.

(40) El "Libro de Varios Asuntos..." en la Biblioteca Nacional de Lima; Sección Manuscritos (D 459). Había sido escrito, según anotación de letra distinta a la del texto, por un pariente de Luis Huerta, el autor del Diccionario de Sinónimos.

Los refranes de Llano Zapata en su "Paremiographo Hispano Latino..." Lima 1752 . 